\title{
Turizm Alanındaki Nitel Araştırmaların Güvenirlik ve Geçerlik Ölçütleri Kapsamında Değerlendirilmesi*
}

Evaluation of Qualitative Researches within the Field of Tourism According to the Criteria of Trustworthiness

\author{
Sinan ŞENER*, Volkan BAHÇECi**, Hümeyra DOĞRU***, Zehra Gökçe SEL****, Mehmet ERTAŞ*****, \\ Seren SONGÜR******, Özkan TÜTÜNCÜ*******
}

*Doktora Öğrencisi, Dokuz Eylül Üniversitesi, Sosyal Bilimler Enstitüsü, Turizm İşletmeciliği Doktora Programı, 35160, Kaynaklar Yerleşkesi, Tınaztepe, Buca, İzmir E-posta: sinansener85@gmail.com

** Araş. Gör., Dokuz Eylül Üniversitesi, İşletme Fakültesi, Turizm Işletmeciliği Bölümü, 35160, Kaynaklar Yerleşkesi, Tınaztepe, Buca, İzmir. E-posta: volkan.bahceci@deu.edu.tr

*** Araş. Gör., Dokuz Eylül Üniversitesi, İşletme Fakültesi, Turizm İşletmeciliği Bölümü, 35160, Kaynaklar Yerleşkesi, Tınaztepe, Buca, İzmir. E-posta: humeyra.dogru@deu.edu.tr

**** Araş. Gör., Dokuz Eylül Üniversitesi, İşletme Fakültesi, Turizm İşletmeciliği Bölümü, 35160, Kaynaklar Yerleşkesi, Tınaztepe, Buca, İzmir. E-posta: gokce_doner@hotmail.com

***** Araş. Gör., Dokuz Eylül Üniversitesi, İşletme Fakültesi, Turizm İşletmeciliği Bölümü, 35160, Kaynaklar Yerleşkesi, Tinaztepe, Buca, i̇zmir. E-posta: mertas29@gmail.com

****** Doktora Öğrencisi, Dokuz Eylül Üniversitesi, Sosyal Bilimler Enstitüsü, Turizm İşletmeciliği Doktora Programı, 35160, Kaynaklar Yerleşkesi, Tınaztepe, Buca, İzmir.

E-posta: serensongur@gmail.com

******* Prof. Dr., Dokuz Eylül Üniversitesi, Spor Bilimleri ve Teknolojisi Yüksekokulu, Rekreasyon Bölümü, Sağlık Kampüsü, 35340, İnciraltı, İzmir. E-posta: ozkan.tutuncu@deu.edu.tr

\section{MAKALE BILGILERI}

Makale işlem bilgileri:

Gönderilme tarihi: 1 Temmuz 2016

Birinci düzeltme: 29 A ğustos 2016

Kabul: 12 Ekim 2016

Anahtar sözcükler: Nitel araştırma, Güvenirlik ve geçerlik modeli, Anatolia.

\section{ARTICLE INFO}

Article history:

Submitted: 1 July 2016

Resubmitted: 29 August 2016

Accepted: 12 October 2016

Key words: Qualitative research,

Trustworthiness, Anatolia.
ÖZ

1980'li yıllardan bu yana nitel araştırmalarda güvenirlik ve geçerliği sağlayabilmek için bazı ölçütler belirlenmeye çalışılmaktadır. Özellikle 2000'lerin başında bu ölçütlerin kullanımının yaygınlaştığı görülmektedir. Bu bakımdan ölçütlerin nitel araștırmalarda ne kadar dikkate alındığının tespiti oldukça önemlidir. Bu çalıșmada, Anatolia: Turizm Araştırmaları Dergisi'nde yayınlanan nitel çalışmalar incelenmiş ve bunların nitel araştırmalarda kullanılması gereken güvenirlik ve geçerlik ölçütlerini ne düzeyde karșıladıkları saptanmaya çalıșılmıștır. Bu kapsamda ilgili dergide yayınlanan ve nitel yöntem kullanıldığı belirlenen toplam 31 çalıșma incelemeye alınmıştır. Araştırmanın bulguları, 1990 yılından 2007 yılına kadar yayınlanan çalışmaların, nitel araştırmalar için gerekli olan güvenirlik ve geçerlik ölçütlerinin çoğunu karşılamadığını, öte yandan 2007 yılından sonra bu ölçütlere çalışmalarda daha fazla yer verildiğini göstermiştir.

\section{ABSTRACT}

Since 1980s, there was an ongoing effort to define some certain criteria in terms of providing validity and reliability in qualitative research. Particularly in the beginning of 2000 s, it was observed that usage of these criteria has been more common. It was important to examine the extent of conformation to these criteria in qualitative studies. In this research, qualitative articles that were published in Journal of Anatolia Tourism Research have been examined in terms of the level of usage of these criteria in qualitative articles. 31 qualitative articles have been identified in this regard. The findings of the study revealed that the articles published between 1990 and 2007 did not compensate the most of validity and reliability criteria, whereas the ones published after 2007 s covered more of these criteria.

\footnotetext{
* Bu makale, 29.04.2016-30.04.2016 tarihleri arasında Nevşehir, Avanos'ta düzenlenen 8. Lisansüstü Turizm Öğrencileri Araştırma Kongresi'nde özet olarak sunulan ve bildiri kitabında yayınlanan "Turizm Alanındaki Nitel Araştırmalarda Uygulanan Yöntem Ölçütlerinin Değerlendirilmesi" başlıklı bildirinin geliştirilmiş halidir.
}

\section{GíRiş}

Genel olarak araştırmaların güvenirliği ve geçerliği yapılan çalışmaların tasarım ve uygulama aşamalarında gösterilen özenle doğrudan ilişkili olarak görülmektedir. Bu kapsamda, tüm 
araştırmaların özenle tasarlanıp uygulanması, okuyucuya, uygulayıcılara ve diğer araştırmacılara doğru ve haklı görünecek sonuçlar sunması beklenmektedir (Merriam 2013). Nitel araştırma yöntemi kullanılan çalışmaları daha güvenilir ve geçerli kılabilmek adına kullanılan stratejileri, Guba'nın (1981) güvenirlik ve geçerlik modeli kapsamında inceleme altına alan Shenton (2004) "credibility" (inandırıcılık), "transferability" (aktarılabilirlik), "dependability" (tutarlılık) ve "confirmability" (doğrulanabilirlik) ana ölçütleri kapsamında değerlendirmektedir. Gerçekleştirilen bu araştırmada, Anatolia Turizm Araştırmaları Dergisi'nde (Anatolia) 2016 yılına kadar yayımlanan nitel araştırmaların, Shenton'ın (2004) Guba (1981) tarafından geliştirilmiş olan güvenirlik ve geçerlik modelini temel alarak derlediği ölçütler kapsamında değerlendirilmesi amaçlanmıştır.

\section{NiTEL ARAŞTIRMALARDA GÜVENIRLiK VE GEÇERLIK MODELI}

Nitel yöntem kullanılan araştırmaların objektif bakış açısı ile yürütülmesi ve bunun tarafsız bir şekilde kamuoyuna sunulmasının zorluğuna işaret eden bazı çalışmalarda (Maxwell 1992; Creswell 2003; Wiersma ve Jurs 2005), “araştırmada güvenirlik ve geçerlik" esaslarında adaptasyon sürecinin gerekliliğine vurgu yapılmaktadır. Nitel araştırma yöntemlerinde bir genellemeye varmanın güç olması sebebiyle nicel yöntemlerde kullanılan güvenirlik ve geçerlik ölçütlerinin veya ölçümlerinin nitel yöntemlere uygulanması mümkün olmamaktadır. Bu durumun altında yatan temel neden, nitel ve nicel paradigmaların bu konudaki söylemlerinin farklı olması ve nicel bir çalışmada bütün prosedürlerin uygulanarak üçüncü tarafların ikna edilmesi söz konusu iken nitel araştırmalarda çıkan sonucun mantıklı olduğunun kanıtlanmasına ve okuyucunun ikna edilebilmesine yönelik detaylı betimlemelerin verilmesidir (Firestone 1993).

Nitel araştırmalarda güvenirlik ve geçerlik konusu çeşitli araştırmacılar tarafından birbirinden farklı yaklaşımlarla ele alınmıştır. Bu kapsamda gerçekleşen araştırmaların bu konuda geliştirmiş olduğu farklı kıstaslar, sonraki çalışmalara önderlik etmiştir (Krefting 1991; Maxwell 1992; Fi- restone 1993; Miles ve Huberman 1994; Merriam 1995; Padgett 1998; Creswell 1998; Healy ve Perry 2000; Thomas ve Magilvy 2011).

Eisner (1991), güvenirlik ve geçerliği yapısal doğrulama, mutabık geçerlik ve bilgi yeterliliği terimleri ile ifade ederken, Maxwell (1992) betimsel geçerlik, yorumlayıcı geçerlik, kuramsal geçerlik, genellenebilir geçerlik ve değerlendirmeci geçerlik olarak beş boyutta sınıflandırmaktadır. Merriam (1995) bu konuda iç geçerlik, güvenirlik ve dış geçerlik olmak üzere üç ölçüt önerirken, Angen (2000) geçerliğin bir araştırmanın güvenirliğinin ve kalitesinin muhakemesi olduğunu belirtmekte ve etik geçerlik ve sürekli geçerlik olmak üzere iki tür geçerlikten söz etmektedir. Whittemore, Chase ve Mandle (2001) nitel araştırmalarda geçerlik ve güvenirliğin birincil ve ikincil ölçütlere bağlı olduğunu ve bu ölçütleri karşılamak için yapılması gereken bazı teknikler olduğunu ifade etmektedir. Birincil ölçütler güvenirlik, özgünlük, eleştirellik, dürüstlük iken ikincil ölçütler açıklık, canlılık, yaratıcılık, tamlık, mutabakat ve hassasiyettir.

Bu çalışmalardan farklı olarak nitel araştırmalarda güvenirlik ve geçerlik konusuna eleştirel bir bakış açısı getiren araştırmacılar da bulunmaktadır. Örneğin; Wolcott (1990) geçerliğin ne yol gösterdiğini ne de bilgi verdiğini iddia etmekte ve nitel araştırmalardaki amacın eleştirel unsurları belirlemek ve bunlardan mantıklı yorumlar yazmak olduğunu belirtmektedir. Wolcott (1990) araştırmacıların güvenirlik ve geçerlik ölçütlerine dikkat ederken, araştırmanın özünden uzaklaşabildiklerini belirtmekte, bu nedenle geçerlik terimi yerine "anlayış" terimini önermektedir. Kvale (1995) ise nitel çalışma geleneğinde geçerlik arayışında kesin kanıtlar bulunamayacağını ifade etmektedir.

Nitel araştırmalarda, araştırmacıdan ve katılımcılardan kaynaklı ön yargıları veya tehditleri önlemek ve sonuçların objektif bir şekilde verilebilmesini sağlamak için araştırmacılar tarafından izlenmesi gereken bazı stratejiler bulunmaktadır (Creswell 1998). Bu kapsamda yapilan alanyazın taramasında nitel araştırmalarda güvenirlik ve geçerlik koşullarının sağlanmasına yönelik 
öneriler getiren çalışmaların incelenmesi sonucu farklı yazarlar tarafından ortaya konmuş birtakım stratejilere Tablo 1'de yer verilmiştir.

Tablo 1. Nitel Araştırmalarda Güvenirlik ve Geçerliğin Sağlamasına Yönelik Ortaya Konmuş Temel Stratejiler

\begin{tabular}{|c|c|}
\hline Stratejiler & Araştrrmalar \\
\hline \multirow[t]{4}{*}{ Katılımcı Teyidi } & Lincoln ve Guba 1985 \\
\hline & Maxwell 1992 \\
\hline & Merriam 1995 \\
\hline & Creswell 1998, 2003 \\
\hline \multirow[t]{3}{*}{ Uzun Süreli Çalışma } & Kirk ve Miller 1986 \\
\hline & Maxwell 1992 \\
\hline & Golafshani 2003 \\
\hline \multirow[t]{5}{*}{ Ayrıntlı Betimleme } & Maxwell 1992 \\
\hline & Creswell 1998, 2003 \\
\hline & Whittemore, Chase ve Mandle 2001 \\
\hline & Patton 2002 \\
\hline & Li 2004 \\
\hline \multirow[t]{3}{*}{ Analiz Formu } & Lincoln ve Guba 1985 \\
\hline & Maxwell 1992 \\
\hline & Creswell 2003 \\
\hline \multirow[t]{7}{*}{ Çeşitleme (Üçleme) } & Guba 1981 \\
\hline & Lincoln ve Guba 1985 \\
\hline & Maxwell 1992 \\
\hline & Creswell 1998, 2003 \\
\hline & Decrop 1999 \\
\hline & Patton 2002 \\
\hline & Horsburgh 2003 \\
\hline \multirow[t]{4}{*}{ Yinelenen Sorular } & Maxwell 1992 \\
\hline & Merriam 1995 \\
\hline & Patton 2002 \\
\hline & Shenton 2004 \\
\hline \multirow[t]{5}{*}{ Rastlantisal Örneklem Seçme } & Guba 1981 \\
\hline & Maxwell 1992 \\
\hline & Hoepfl 1997 \\
\hline & Padgett 1998 \\
\hline & Shenton 2004 \\
\hline \multirow[t]{6}{*}{ Uzman incelemesi } & Krefting 1991 \\
\hline & Erlandson vd. 1993 \\
\hline & Miles ve Huberman 1994 \\
\hline & Creswell 1998, 2003 \\
\hline & Shenton 2004 \\
\hline & Lietz, Langer ve Furman 2006 \\
\hline \multirow[t]{3}{*}{ Vaka Analizi } & Miles ve Huberman 1994 \\
\hline & Creswell 1998, 2003 \\
\hline & Marvasti 2004 \\
\hline \multirow{3}{*}{$\begin{array}{l}\text { Bulguların Literatürle } \\
\text { Kıyaslanması }\end{array}$} & Lincoln ve Guba 1985 \\
\hline & Maxwell 1992 \\
\hline & Daymon ve Holloway 2003 \\
\hline
\end{tabular}

Nitel araştırmalarda güvenirlik ve geçerlik konusunda öncü çalışmalardan biri Guba'ya (1981) ait olup yazar bu kapsamda nitel araştırmalarda "trustworthiness" kavramını güvenirlik ve geçerliğe yönelik unsurları altında toplayan bir çatı kavram olarak ortaya atmıştır. Guba (1981), Türkçe karşılığ1 'güvenilirlik' olan ve yerli yazına da 'güvenirlik' olarak geçmiş olan 'trustworthiness' kavramını Türkçe sözlükteki anlamından daha geniş bir kapsamda güvenirlik ve geçerliği karşılayacak şekilde kullandığı için bu çalışmada da 'trustworthiness' kavramı 'güvenirlik ve geçerlik modeli' olarak ifade edilecektir.

Guba (1981) tarafından geliştirilen ve bu araştırmanın temelini oluşturan güvenirlik ve geçerlik modeli "credibility (inandırıcilık)", "transferability (aktarılabilirlik)", "dependability (tutarlılık)" ve "confirmability (doğrulanabilirlik)" alt başlıklarını içermektedir. Bu alt başlıklara ve Guba'nın (1981) bu modeli ortaya attığ1 dönemde yaygın olan mevcut paradigma içerisinde hangi kavramlara karşılık geldiklerine Tablo 2'de yer verilmiştir.

\section{INANDIRICILIK (CREDIBILITY)}

İnandırıcılık kavramı incelendiğinde ilgili yazında genel olarak "iç geçerlilik" ve "doğruluk değeri" kavramlarına karşılık olarak kullanıldığı görülmektedir (Guba 1981; Shenton 2004; Rapport vd. 2015). Nitel araştırmalarda inandırıcılık, araştırma katılımcılarının aktardıkları deneyimlerin çalışma aracılı̆̆ıyla okuyucuya ne ölçüde doğru ve anlaşılır bir şekilde aktarıldığının ölçütüdür (Thomas ve Magilvy 2011). Diğer bir ifade ile araştırmacının sonuçlarında sunduğu gerçekliğin, katılımcıların ortaya koyduğu gerçeklikle

Tablo 2. Nitel Araştırmalarda Güvenirlik ve Geçerlik Modeli

\begin{tabular}{|c|c|c|}
\hline $\begin{array}{l}\text { Bakış Açısı } \\
\text { Doğruluk değeri }\end{array}$ & $\begin{array}{l}\text { Bilimsel ifade } \\
\text { İç Geçerlik }\end{array}$ & $\begin{array}{l}\text { Güvenirlik ve Geçerlik Model } \\
\text { İnandırıcılık (Credibility) }\end{array}$ \\
\hline Uygulanabilirlik & $\begin{array}{l}\text { Dış Geçerlik } \\
\text { (Genellenebilirlik) }\end{array}$ & $\begin{array}{r}\text { Aktarılabilirlik } \\
\text { (Transferability) }\end{array}$ \\
\hline Tutarlılık & Güvenirlik & Tutarlılık (Dependability) \\
\hline Tarafsızlık & Objektiflik & $\begin{array}{l}\text { Doğrulanabilirlik } \\
\text { (Confirmability) }\end{array}$ \\
\hline
\end{tabular}

Kaynak: Guba (1981). 
örtüşür vaziyette olmasına odaklanır (Sinkovics, Penz ve Ghauri 2008). Bir çalışmanın inandırıcılığını arttırmaya yönelik olarak Shenton (2004) tarafından derlenmiş olan stratejiler bu alanda çalışma yapmış diğer yazarların çalışmalarından da yararlanılarak aşağıdaki şekilde sunulmuştur:

Bir araştırmada inandırıcılığı arttırmak için ilk gereklilik uygun yöntem kullanımı ve uygulamadır (Shenton 2004). Yöntemsel olarak uygunluğun sağlanması için araştırmanın sorusu ile seçilen yöntemin bileşenleri örtüşür vaziyette olmall, soru, yöntem, veri ve analitik süreçler bir bütünlük sağlamalıdır (Morse vd. 2002). Aksi takdirde uygun olmayan bir yöntem ile yapılacak uygulama ya sonuca ulaşmayacak ya da inandırıcı olmayan sonuçlar ortaya koyacaktır.

Bir diğer strateji olarak, uygulama alanını tanımak adına araştırmacının uygulamayı gerçekleştirdiği bölgede fazladan geçirdiği zaman, yerel halkın araştırmacılara alışmasını sağladığı gibi aynı zamanda hem yerel halkın hem de araştırmacıların kendi önyargı ve bakış açılarını yeniden gözden geçirmeleri için bir fırsat sunmaktadir (Guba 1981). Ancak her ne kadar daha kapsamlı veri elde edilmesini sağlasa da bu uygulamada dikkatli olunması gereken husus araştırmacının katılımcılarla kurduğu yakınlığın tarafsızlığını etkilememesidir (Fontana ve Frey 2005).

Shenton (2004), inandırıcılığı sağlamanın bir diğer ölçütü olarak rastlantısal örneklem seçimini ortaya koymakla beraber bu ölçütün nitel araştırmalarda uygulanmasının çok tercih edilir olmadığını da ifade ederek bu ölçüte dair açıklamalarında asıl vurguyu örneklem seçiminin tarafsız olmasına yapmaktadır. Ona göre önemli olan, araştırmacının, rastlantısal olsun veya olmasın örneklem seçimini tarafsız yaptığına dair okuyucuya inandırıcı açıklamalar yapmasıdır. Benzer şekilde Creswell'e (1998) göre de eğer araştırmacı amaçlı bir örneklem seçimine yönelecekse kafasında net ölçütler olmalı ve aldığı kararları okuyucuya rasyonel gerekçelerle açıklayabilmelidir.

Çeşitleme nitel araştırmalarda araştırmanın inandırıcılığının artırılması için kullanılan bir stratejidir (Golafshani 2003). Çeşitleme, tek bir noktanın birbirinden farklı ve bağımsız kaynaklardan ele alınmasıdır. Bir fenomenin veya araş- tırma sorusunun birden fazla veri kaynağından incelenmesi olarak görülmektedir (Decrop 1999). Çeşitleme farklı şekillerde yapılabilmektedir. Bunlardan bazıları yöntemde, veri kaynakların$\mathrm{da}$, araştırmacıda ve teoride çeşitlemedir (Krefting 1991). Araştırmacının farklı kaynaklardan elde ettiği bu bulgular ve yaptı̆̆ çıkarımlar eğer birbirleriyle tutarlılık gösterirse okuyucu açısından araştırmanın bulguları daha ikna edici olacaktır (Carlson 2010).

Elde edilen verinin inandırıcıllı̆̆ından emin olmak için katılımcıların dürüst olmaları teşvik edilmelidir. Sekaran'ın (2003) ifade ettiği şekliyle katılımcılar sonuçlarından korkmadan dürüst ve doğru cevaplar verebilmelerine olanak tanıyacak kadar rahatlatılmalıdırlar. Katılımcıların gönüllü olarak katılan kişiler olması ve görüşülen kişilere daha çok konuşma fırsatı verilmesi de bunun bir yoludur (Kozak 2014). Ayrıca, katılımcılara araştırmanın amac1, yöntemi, kendilerinden toplanan verinin ne şekilde kullanılacağı, anonimliklerinin nasıl korunacağı ve özellikle kendilerinden beklenenin ne olduğu konusunda açık ve net bilgiler verilmelidir (Li 2004).

Yinelenen sorular sorma stratejisi de katılımc1ların dürüstlügüne benzer şekilde elde edilecek verinin inandırıcılı̆̆ını denetlemeye yönelik bir stratejidir. Krefting'e (1991) göre bir araştırmaC1 sorularına aldığı yanıtlardan emin olmak için görüşme sürelerini uzatarak, önceden sorduğu soruları farklı şekillerde yeniden kurgulayarak olumlu ve olumsuz cevaplar arasındaki tutarl1lığ kontrol etmelidir. Bu sayede hangi verilerin analize dahil edileceği ve hangi katılımciların tutarlı veri sağladığı tespit edilmiş olacaktır.

Bir diğer yöntem olan olumsuz vaka analizi araştırmanın şablonuna uymayan yapıların araştırılmasıdır. Patton'a (1999) göre ortaya konan modele uymayan bu olumsuz vakalar araştırmacının model anlayışını zenginleştirirken kuralı genişletebilir, şüpheli hale getirebilir veya değiştirebilir; ancak etkisi ne olursa olsun araştırmacıyı bütünü anlamaya daha da yaklaştırır. Araştırmacı araştırmanın süreci boyunca her aşamada elindeki veriye geri dönüp vakaların ne kadarını karşıladığını tekrar tekrar kontrol etmelidir (Shenton 2004). 
İnandırıcılık adına yapılan uygulamaların en yaygin olanlarından biri olan uzman incelemesi, araştırma sürecinin ve bulgularının araştırma yöntemlerine dair bilgisi ve deneyimi olan tarafsız kişilerle paylaşılması ve onların fikirlerine başvurulmasıdır (Krefting 1991). Li'ye (2004) göre araştırmacı sürekli benzer çalışmalar yapan profesyonellerle iletişim halinde olmalı ve çalışmasına dair ortaya atılabilecek soruları cevaplamaya çalışmalıdır. Bu sayede onların katkılarıyla çalışma geliştirilebilecek ve problem yaratabilecek hususlar tespit edilebilecektir.

Araştırmacının yorumu da uzman incelemesi gibi dış değerlendirmelere ek olarak araştırmacının kendisinin de araştırmasının ilerleyişini sürekli takip etmesi ve yorumlamasıdır. Araştırmacı bu sayede araştırmasının ve kendisinin ilerleyişi, uyguladığı yöntemlerin işlevselliği üzerine çıkarımlar yapabilir (Shenton 2004). Bu bağlamda, Morse vd. (2002) bazı hataların düzeltilebilmesi için çok geç olan bir aşamada fark edilmesinden kaçınmak adına araştırmacının çalışmasını sadece tamamlandığında değil, sürecin her aşamasında denetlemesinin gerekliliğinin altını çizmişlerdir.

Bir diğer strateji ise okuyucunun araştırmactnın geçmişi ve deneyimi hakkında bilgilendirilmesidir. Araştırmacının belirli bir konu üzerinde neden çalıştığı, ne gibi bağlantıları olduğu, kişisel deneyimleri, ne kadar eğitimli olduğu gibi araştırmacıya yöneltilebilecek pek çok soruya yanıt verebilmek için araştırmanın raporunda araştırmacı ile ilgili bu gibi bilgilere de yer verilmesi gerekmektedir (Patton 1999). Araştırmacı hakkında bilgi sahibi olan okuyucu araştırmacının araştırmasında nerede durduğu ve bu araştırmayı ne ölçüde yeterlilikle yürüttüğü gibi pek çok konuda fikir sahibi olabilecektir.

Williams ve Morrow (2009), bir araştırmada inandırıcılıktan bahsedebilmek için katılımcıların söyledikleri ile araştırmacının söylenenleri ne şekillerde yorumladığı arasında bir denge olması gerektiğini vurgulamaktadırlar. Bu dengeyi sağlamak için gerçekleştirilen katılımcıların kontrolü katılımcılardan toplanan verinin onlara geri sunulmasıdır. Bu sayede katılımcilardan elde edilen ek bilgi ve fikirler sayesinde araştırmacı konuya dair yeni bir kavrayış geliştirebilir ve katılımcların deneyimini daha bütünlemesine değerlendirebilir (Kornbluh 2015).

İnandırıcılığ 1 sağlamanın bir başka yolu ise araştırılan olgunun kavramsal çerçevesinin yeterliliğidir. Araştırmaya temel oluşturacak ve araştırmacıya yol gösterecek kuramsal bir çerçevenin açık bir biçimde oluşturulması gerekmektedir (Miles ve Huberman 1994). Her ne kadar nitel araştırmalarda net bir kavramsal temel oluşturmak bazen başta mümkün olmasa da araştırmacı hâlihazırda yapılmış araştırmalardan yola çıkarak araştırmasının ilgili alanda önemli olduğuna ve alanyazına katkı getireceğine okuyucuyu inandırmalıdır (Yıldırım ve Şimşek 2013).

Son olarak, Williams ve Morrow (2009) bulguların literatürle kıyaslanmasını, bir araştırmanın sonuçlarının mevcut yazınla ne kadar ilişkili olduğunun dikkate alınması olarak tanımlarken, Shenton (2004) önceden aynı yerde ya da aynı örnekleme uygulanmış benzer çalışmaların sonuçlarını, elde edilmiş bulguların değerlendirilmesi ve tutarlılığının kontrol edilmesi açısından önemli kaynaklar olarak nitelendirmektedir.

\section{AKTARILABILIRLIK (TRANSFERABILITY)}

Nitel araştırmalarda aktarılabilirlik, araştırma bulgularının bir gruptan diğerine aktarılabilmesi ile doğrudan ilintilidir (Lincoln ve Guba 1985). Nicel araştırmalarda aktarılabilirlik dış geçerlilik ile açıklanmakta, örneklemden elde edilen bulguların evrene genellenebilmesi olarak tanımlamakta ve bunun sağlanmasında örnekleme tekniğinin önemine dikkat çekilmektedir (Payton 1979). Nicel araştırmalarda araştırmacının sorumluluğu evrene genelleme yapmak iken nitel araştırmalarda araştırmacı elde ettiği sonuçların benzer özellik taşıyan olay ve olgulara aktarılabilirlik değerini ortaya koymalıdır (Erlandson vd. 1993).

Diş geçerliğin sadece nicel araştırmalarda mümkün olduğunu savunan pozitivist görüşe karşın, post-pozitivistler nicel yaklaşımlardan farklı uygulamalarla geçerliğin nitel araştırmalarda da sağlanabildiğini savunmaktadırlar (Maxwell 1992). Benzer şekilde Devers (1999) 
nitel araştırmalarda genellenebilirliğin mümkün olduğunu savunarak genelleme kelimesi yerine aktarılabilme kavramını desteklerken, Denscombe (2010) araştırılan her durumun benzersiz olmasına karşın örneklemin daha geniş bir grubu temsil etmekte olduğunu savunmaktadır. Son olarak Guba (1981) nitel araştırmalarda genellemenin bir dereceye kadar mümkün olduğunu belirtirken, bu genellemenin ön koşulu olarak genellenen bulgu ve genelleneceği ortama dair çok geniş çaplı ve detaylı bilgiye sahip olmanın gerekliliğini ortaya koymuştur.

Araştırmacı okuyucunun benzer araştırmayı yapabilmesine imkân sağlayacak şekilde alan araştırmasını gerçekleştirdiği bağlamsal durum hakkında yeterli bilgiyi sağlamalıdır (Lincoln ve Guba 1985). Bu nedenle araştırmacının aktarılabilirlik ölçütünü karşılayabilmesi için araştırma raporunda Kurum/İsletme Sayısı, Katılımcilarla Ilgili Kısıtlar, Katılımo Sayısı, Veri Toplama Yöntemlerinin Uygulanışı, Yöntemin Uygulanma Süresi ve Verinin Toplandı $\breve{g} \imath$ Zaman Aralığı hakkında bilgi vermelidir (Shenton 2004). Araştırmacı bulguların ortaya çıktığı koşulların kilit unsurlarını açılayarak okuyucunun, bulguların diğer durumlara uygulanabilme derecesine karar vermesini mümkün kılmalıdır. Bulguların aktarılabilir olması için koşullar benzer olmalıdır (Devers 1999).

Yukarıda verilen çeşitli açıklamalar ve ortaya konmuş ölçütler göz önüne alındığında genellenebilirlik ifadesinin nitel araştırmalar için de alanyazında ziyadesiyle kullanıldığı görülmektedir. Bununla birlikte bu post-pozitivist görüşe nitel çalışmalar için bu çalışmanın yazarları katılmamaktadır. Her ne kadar bu görüşe yazarlar katılmıyor olsa da alanyazındaki kullanımından dolayı çalışma içerisinde genellenebilirliğe yer verilmiş ve alanyazında geçen ölçütler açısından değerlendirmeye dahil edilmiştir.

\section{TUTARLILIK (DEPENDABILITY)}

Nitel araştırmalarda güvenirlik ve geçerlik modelinin ölçütlerinden üçüncüsü olan verinin tutarlılığı, araştırmanın aynı katılımcılarla ya da benzer bağlamda tekrar edilmesi durumunda tu- tarlı sonuçlar ortaya çıkıp çıkmayacağını göstermektedir (Krefting 1991; Charles 1995; Merriam 1995; Berg 2000; Stenbacka 2001; Golafshani 2003; Taylor ve Wallace 2007). Diğer bir deyişle, eğer çalışma aynı içerik, aynı yöntem ve aynı katılımcılar ile tekrarlanırsa ve benzer sonuçlar elde edilirse, bu durum çalışmanın ilk uygulandığında da araştırmacı tarafından sonuçlara etki edilmediğini işaret edeceğinden çalışmanın inand1rıcı ve tutarlı olduğu sonucuna varılabilir (Brink 1993; Shenton 2004). Lincoln ve Guba'ya (1985) göre tutarlılık, araştırma sonuçlarını etkileyebilecek tüm faktörler kontrol altında tutulduğunda ve araştırma araştırmacının tarif ettiği gibi tekrarlandığında elde edilen bulguların önceki bulgularla olan benzerlik ya da tutarlılık derecesidir. Lincoln ve Guba (1985) inandırıcılık (credibility) ve tutarlılık (dependability) arasında yakın bağlar olduğunu vurgulamakta ve tutarlılığın odak grup ve bireysel mülâkat gibi örtüşen yöntemlerin bir arada kullanılması ile sağlanacağını belirtmektedirler. Guba (1981) örtüşen yöntemleri, birinin zayıf yönlerinin diğeri tarafından telafi edildiğ ve bu sayede çalışmanın yöntemsel yeterliliğinin artırıldığı, birbirini tamamlayan yöntemler olarak tanımlamaktadır.

Tutarlılığın sağlanması için gerekli olan diğer bir ölçüt ise çalı̧ma tasarımının detaylıca tanımlanması ve böylece okuyucunun araştırmacı tarafından izlenen karar aşamalarını takip edebilmesidir (Thomas ve Magilvy 2011). Okuyucuların yöntemleri ve etkinliğini anlayabilmeleri için araştırmacı metinde araştırmanın tasarım, uygulama ve planından bahsetmelidir (Shenton 2004). Araştırmanın yapısının, katılımcılarının ve konusunun detaylı ve kapsamlı şekilde sunulması, okuyucuya araştırmanın unsurlarını kendi deneyimleri ile kıyaslayarak bulguların gerçekçiliğini test etme şansı tanımakta (Creswell ve Miller 2000) ve süreci anlayarak takip etmesine yardımcı olarak okuyucuya aynı zamanda kendisine detay verildiğini hissettirmektedir (Curtin ve Fossey 2007). Daha sonra veri toplama sürecinin işlemsel detayı ile alanda ne yapıldı $\breve{g} 1$ ayrıntılı bir şekilde anlatılmalıdır. Son olarak, araştırmacının öz değerlendirmesi ile yürütülen araştırma sürecinin etkinliği sorgulanmalıdır (Shenton 2004). 


\section{DOĞRULANABILIRLIK (CONFIRMABILITY)}

Nitel araştırmalardaki doğrulanabilirlik kavra$\mathrm{m}$ araştırmacının tarafsız olma kaygısı ile aynı anlamda kullanılmaktadır (Erlandson vd. 1993). Tarafsızlık araştırma bulgularının araştırmacının önyargıları, güdüleri, çıkarları veya bakış açısının etkisinde kalmadan sadece katılımcıların verdiği cevaplar ve araştırmanın şartları doğrultusunda elde edilme derecesi olarak tanımlanmaktadır (Guba 1981). Krefting'e (1991) göre, nitel araştırmalarda tarafsızlığın sağlanması için araştırmacı ile katılımcilar arasında uygun bir mesafe olma1 , araştırmacı hem araştırmadan etkilenmeyen hem de araştırmayı etkilemeyen birisi olmalıdır. Araştırmacılar sonuçlarının kendi yargı ve bakış açılarından değil, araştırmalarının bulgularından kaynaklandığına dair doğrudan katılımcılar ve içerik ile ilintili sağlam kanıtlar sunmalıdırlar (Devers 1999).

Araştırmalarda doğrulanabilirlik ölçütünün karşılanması için uygulanması gereken bazı stratejiler söz konusudur (Shenton 2004). Öncelikle kişisel ya da yöntemsel önyargıların sınırlandırılması ve araştırmanın doğrulanabilirliğinin artırılması için uygulanması gereken ilk strateji çeşitlemedir (Decrop 1999). Patton'a (1999) göre tek bir yöntem problemi çözmek için yeterli olmayabilir. Dolayısıyla araştırmada birden fazla veri toplama ya da analiz yöntemi kullanmak araştırmanın güvenirlik ve geçerliğini artırmaktadır.

İkinci olarak, araştırmacının inanç ve varsayımlarının belirtilmesi gerekmektedir. Araştırmanın başında öngörülen sonuçlara bulgularda ulaşılıp ulaşılmadığ 1 belirtilmeli ve bulgulardan elde edilen sonucun araştırmacının bakış açısını nasıl değiştirdiği açıklanmalıdır (Guba 1981). Nicel araştırmalardaki yapısal geçerliğe benzer bir şekilde nitel araştırmalarda araştırmacı araştırmayı etkileyen kendi önyargılarını eleştirebilmeli ve yansitabilmelidir (Thomas ve Magilvy 2011). Ayrica araştırmanın başında öngörülen fakat verilerden ulaşılamayan teoriler açıklanmalıdır (Shenton 2004).

Üçüncü olarak, doğrulanabilirlik ölçütünün sağlanabilmesi için araştırma yöntemlerinin sınırlliklarmın ve bunlarm potansiyel etkilerinin belirtilmesi gerekmektedir (Shenton 2004). Bulguların diğer durumlara ya da katılımcllara genellenebilmesini engelleyen sinırlılıklara özellikle nitel çalışmalarda değinilmesi yerinde olacaktır (Elliott, Fischer ve Rennie 1999). Daha sonra, uygulanan yöntemin diğer veri toplama yöntemleri yerine neden tercih edildiğinin belirtilmesi için araştırma yöntemlerinin derinlemesine aktarılması gerekmektedir (Shenton 2004).

Son olarak, uygulanabilecek bir diğer strateji de diyagram oluşturulmasıdır. Araştırma süresince alınan kararların ve prosedürlerin şematik olarak gösterilerek izlenen sürecin adım adım takip edilmesine imkân verilmesi araştırmanın doğrulanabilirliğini arttırmaktadır (Shenton 2004). Araştırmacının çalışma süresince izlediği yolun işlem şemasını veya aldığı kararların bir özetini doküman halinde sunması okuyucuya kolaylık sağlayacak ve araştırmanın niteliğini artıracaktır (Twycross ve Shields 2005).

\section{YÖNTEM}

Bu çalışmanın amacı, Anatolia: Turizm Araştırmaları Dergisi'nde yayınlanan ve nitel araştırma yöntemleri kullanılarak yapılan çalışmaların, Shenton'ın (2004) derlemiş olduğu güvenirlik ve geçerlik modelinin ölçütleri kapsamında, yıllar bazında değerlendirilmesidir. Araştırma kapsamında ele alınan araştırma alanının seçim nedeni, Anatolia: Turizm Araştırmaları Dergisi'nin Türkiye'de kuruluş yılı itibariyle turizm alanında en eski ve kesintisiz yayın yapan öncü bir dergi olmasından ötürü süreçsel bir incelemeye imkân tanımasıdır. Çalışmada yer alan araştırmacılardan birisinin ilgili dergide editörlük yapması ve diğer yazarların da turizm alanında çalışmalar yapıyor olmaları önemli kıstaslar arasındadır.

Çalışma, turizm alanında nitel araştırma yöntemleri kullanılarak oluşturulmuş akademik çalışmaların yıllar bazında güvenirlik ve geçerlik kapsamında nasıl bir değişime tabi olduğunu ortaya çıkarabilmek adına önem arz etmektedir. Bu kapsamda Shenton'ın (2004) Guba'dan (1981) esinlenerek oluşturduğu nitel araştırmalarda güvenirlik ve geçerlik ölçütleri bu araştırmaya uyarlanmış ve nitel yöntem kullanılarak gerçekleştirilen 31 çalışma tespit edilerek değerlendirme altına alınmıştır. Bu çalışmada bibliyogra- 
fi türündeki ve çeviri olan araştırmalar kapsam dışında tutulmuştur. Guba'nın (1981) geliştirdiği "güvenirlik ve geçerlik modeli" çerçevesinde dört temel ölçütün (inandırıcılık, aktarılabilirlik, tutarlılık ve doğrulanabilirlik) yer alması ile beraber, Shenton (2004) bu dört temel ölçütün altında 27 alt ölçüt oluşturmuştur. Bu doğrultuda inandırıcılık için 14, aktarılabilirlik için altı, tutarlılık için iki ve son olarak doğrulanabilirlik için beş alt ölçüt bulunmaktadır.

Bu çalışmada yapılan analizlerde inandırıcılık ölçütü altında yer alan "üstlere bilgi verme" ve "uzman incelemesi" alt maddelerinin birbirine yakın olduğu düşünülmüş ve "uzman incelemesi" başlı̆̆ 1 altında birleştirilmiştir. Çalışmada diğer üç temel ölçütün altındaki alt maddeler ise değiştirilmeyerek toplam 26 alt ölçüt temel alınarak değerlendirme yapılmıştır. Oluşturulan değerlendirme formu alanında uzman iki akademisyenin görüşü de alınarak son hâline getirilmiştir. Alt ölçütlerden, hem inandırıcılık hem de doğrulanabilirlik ana ölçütü altında yer almakta olan "çeşitleme", bulgular yorumlanırken sadece inandırıcılık başlığı altında ele alınmıştır.

Araştırmada veri toplama yöntemi olarak doküman incelemesi yapılmıştır. Toplanan veriler ise betimsel analiz ile işlenmiştir. Son olarak, bulgular çalışmalardan örnek alıntılar yapılarak yorumlanmıştır. Doküman incelemesi tek başına bir veri toplama tekniği olarak ele alınabileceği gibi aynı zamanda araştırmanın temel sorunsalı çerçevesinde de araştırmaya dahil edilebilir (Yıldırım ve Şimşek 2013). Araştırma kapsamında kullanılan betimsel analiz ise elde edilen bulguların düzenlenmiş ve yorumlanmış bir şekilde okuyucuya sunulmasıdır (Büyüköztürk 2007). Bu doğrultuda Anatolia: Turizm Araştırmaları Dergisi'nin 1990-2015 yılları arasında yayınlanan tüm sayılarına 30.11.2015 - 05.02.2016 tarihleri arasında derginin resmi internet sitesinden (anatoliajournal.com/atad/2016) ulaşılmıştır.

İlk olarak rastgele seçilen iki çalışma deneme amaçlı değerlendirmeye alınmıştır. Bu değerlendirmeler esnasında, kesin olarak kullanılacak alt ölçütlere ve ölçütlerin çalışmalarda nasıl tespit edilebileceğine karar verilmiştir. Çalışmanın her aşamasında ölçütler yeniden gözden geçirilmiş, ortaya yeni durumlar çıktığında ise tüm çalışmalar geriye dönülerek revize edilmiştir. Tüm çalışmalar yedi araştırmacının katıldığı toplam dokuz adet toplantı sonucunda her bir alt ölçüt üzerinde fikir birliği sağlanana kadar tartışılarak analiz edilmiştir. Çalışmalar analiz edilmeden önce tüm araştırmacılar tarafından okunmuş, ardından analiz sürecinde her bir çalışmaya 40 ila 90 dakika süre ayrılmıştır. Değerlendirme sonucunda alt ölçütler "Var", "Yok" veya "Ölçülemez" şeklinde sınıflandırılmıştır. İçerisinde ilgili ölçütün varlığına dair net açıklama veya kanıt bulunan çalışmalar "Var" olarak, herhangi bir açıklama veya kanit bulunamayan çalışmalar "Yok" olarak değerlendirilirken, benimsenen veri toplama veya analiz yönteminin doğası gereği ya da örneklemin yapısı gereği ilgili ölçütü zaten karşılama imkânı olmayan çalışmalar ise "Ölçülemez" olarak sinıflandırılarak değerlendirme dışı bırakılmıştır. Araştırma sürecinin aşamaları Şekil 1'de gösterilmektedir.

\section{BULGULAR}

Anatolia: Turizm Araştırmaları Dergisi'nde 19902015 yılları arasında yayınlanan 31 nitel araştırma tespit edilerek 26 ölçüt üzerinden değerlen-

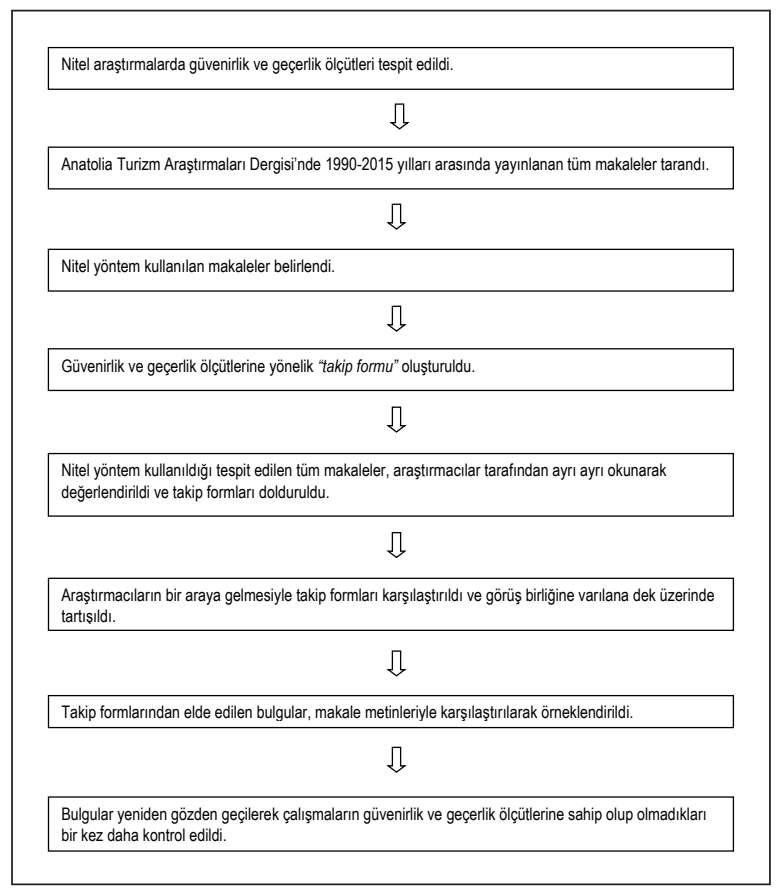

Şekil 1. Araştırma Süreci 
Tablo 3. Nitel Çalışmaların Güvenirlik ve Geçerlik Ölçütlerine Göre Değerlendirilmesi

\begin{tabular}{|c|c|c|c|c|c|}
\hline Temel Ölçütler & Alt Ölçütler & $\begin{array}{r}\text { Var } \\
n\end{array}$ & $\begin{array}{r}\text { Yok } \\
n\end{array}$ & $\begin{array}{r}\text { Ölçülemez } \\
n\end{array}$ & $\begin{array}{r}\text { Toplam } \\
n\end{array}$ \\
\hline & Uygun Yöntem Kullanımı ve Uygulama & 22 & 9 & 0 & 31 \\
\hline & Uygulama Alanını Tanıma & 5 & 26 & 0 & 31 \\
\hline & Rastlantısal Örneklem Seçimi & 25 & 6 & 0 & 31 \\
\hline & Çeşitleme & 13 & 18 & 0 & 31 \\
\hline & Katilımcıların Dürüstlüğü & 4 & 22 & 5 & 31 \\
\hline \multirow[t]{10}{*}{ inandırıcilık } & Yinelenen Sorular & 0 & 24 & 7 & 31 \\
\hline & Olumsuz Vaka Analizi & 1 & 3 & 27 & 31 \\
\hline & Uzman incelemesi & 8 & 23 & 0 & 31 \\
\hline & Araştırmacının Yorumu & 0 & 31 & 0 & 31 \\
\hline & Araştırmacının Geçmiş ve Deneyimi & 1 & 30 & 0 & 31 \\
\hline & Katilımcıların Kontrolü & 4 & 22 & 5 & 31 \\
\hline & Araştrılan Olgunun Kavramsal Çerçevesinin Yeterliliği & 0 & 0 & 31 & 31 \\
\hline & Bulguların Literatürle Kıyaslanması & 15 & 16 & 0 & 31 \\
\hline & Kurum/İşletme Sayısının Belirtilmesi & 20 & 7 & 4 & 31 \\
\hline & Katılımcılarla İlgili Kısıtlar & 16 & 15 & 0 & 31 \\
\hline \multirow[t]{4}{*}{ Aktarılabilirlik } & Katlımcı Sayısı & 25 & 6 & 0 & 31 \\
\hline & Veri Toplama Yöntemlerinin Uygulanışı & 29 & 2 & 0 & 31 \\
\hline & Yöntemin Uygulanma Süresi & 9 & 22 & 0 & 31 \\
\hline & Verinin Toplandığı Zaman Aralığı & 12 & 19 & 0 & 31 \\
\hline \multirow[t]{4}{*}{ Tutarlılık } & Örtüşen Yöntemlerin Kullanılması & 8 & 23 & 0 & 31 \\
\hline & Çalışma Tasarımının Detaylıca Tanımlanması & 22 & 9 & 0 & 31 \\
\hline & Çeşitleme & 13 & 18 & 0 & 31 \\
\hline & Araştırmacının İnanç ve Varsayımları & 15 & 16 & 0 & 31 \\
\hline \multirow[t]{3}{*}{ Doğrulanabilirlik } & Yöntemin Sınırlıık ve Potansiyel Etkileri & 12 & 19 & 0 & 31 \\
\hline & Yöntemin Derinlemesine Aktarılması & 16 & 15 & 0 & 31 \\
\hline & Diyagram & 1 & 30 & 0 & 31 \\
\hline
\end{tabular}

dirilmiştir. Yapılan analiz sonucunda elde edilen bulgular Tablo 3'te sunulmaktadir.

Araştırmada, yıllar bazında incelendiğinde 1990-2006 yılları arasında yayınlanan çalışmalar ile 2007'den sonrakiler arasında güvenirlik ve geçerlik ölçütlerinin karşılanma düzeyleri açısından farklılıklar olduğu tespit edilmiştir. Buna göre 2006'ya kadar yapılan çalışmalarda ölçütlerin karşılanma oranı ortalama \%21 olarak ölçülürken, 2007 ile 2015 yılları arasında yapılan nitel çalışmaların ölçütleri karşılama oranı \%54 olarak tespit edilmiştir. Şekil 2'de çalışmaların tarihleri ve bu çalışmada ortaya konulan güvenirlik ve geçerlik ölçütlerini karşılama oranı verilmektedir.

İlgili araştırmalar, inandırıcılık ana ölçütü kapsamında 13 alt ölçüt üzerinden değerlendirilmiş- tir. Değerlendirme sonuçlarına göre, çalışmaların inandırıcılık ölçütü açısından sadece altı tanesinin alt ölçütlerinin \%50'sinden fazlasını karşıladı̆̆ı anlaşılmıştır. Özellikle 1990-2006 yılları arasındaki çalışmalarda güvenirlik ölçütlerinin \%50'sinden fazlasını karşılayan hiçbir çalışma bulunamamıştır.

İlk olarak uygun yöntem kullanımı ve uygulama açısından yapılan değerlendirmede, çalışmaların 22 tanesinde, araştırmacıların kullandıkları yöntemi nasıl kurguladıklarına dair bilgi verdikleri görülmüştür. Özellikle 2004 yılına kadar yapılmış olan 13 çalışmanın dokuzunda araştırmada kullanılan yöntemin nasıl kurgulandığına dair bir bilgiye ulaşılamazken, bu tarihten sonra yapılmış olan tüm çalışmalarda ise bu konuya 


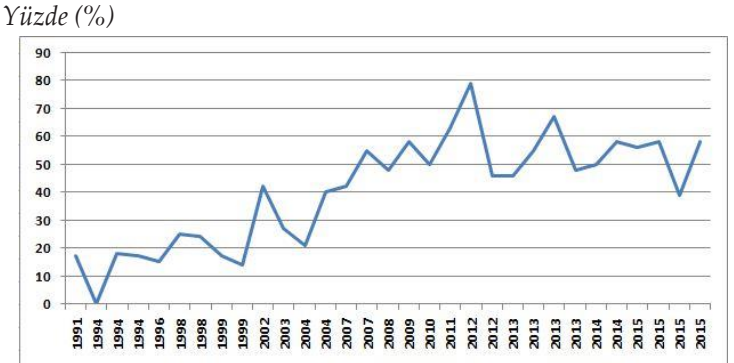

Şekil 2. Nitel Çalışmaların Güvenirlik ve Geçerlik Modelinin Ölçütlerini Karşılama Oranının Yıllara Göre Dağılımı

dair bilgilerin yöntem kısmında verildiği görülmektedir. Aşağıda bir örnek verilmektedir:

"Görüşme formunun oluşturulmasinda sorular, araştırmanın yazın taramasından ve Tataroğlu'nun (2006: 236-237) görüşme formundan oluşturulmuş ve bağımsız iki akademisyenin görüşleri doğrultusunda son halini almıştır." (Çalışma 22)

Uygulama alanını tanıma ölçütü açısından yapılan değerlendirmede, çalışmaların 26 tanesinde araştırmacıların uygulama alanını tanıdıklarına dair bir bilgi vermedikleri sonucu ortaya çıkarken, sadece tamamı 2009 yılından sonra yayınlanmış olan beş çalışmada araştırmacıların bu konuda bilgi verdikleri sonucu ortaya çıkmıştır. Bu sonucun ortaya çıkmasında, araştırmacıların çoğunun uygulama alanını tanıyor olmalarının beklenmesine karşın, bunu çalışmalarına yansıtmamış olabileceği ihtimali göz önünde bulundurulmalıdır. Engelli turistlere yönelik yapılmış bir çalışmada, yazarlar uygulama alanını tanıdıklarını şu ifadeyle çalışmalarında yansıtmıştır:

"Görüşmeler, projenin engelli eğitim uzmanı olan bu çalışmanın ikinci yazarı tarafından gerçekleştirilmiştir." (Çalışma 27)

Rastlantısal örneklem seçimi ölçütü açısından yapılan değerlendirmede, çalışmaların 25 tanesinde araştırmacıların uygulama alanına uygun örneklemi nasıl seçtiklerini belirten bilgileri verdikleri saptanmıştır. Çalışmaların altı tanesinde ise araştırmacıların örneklem seçimleriyle ilgili herhangi bir bilgiye ulaşılamamıştır. Aşağıda bir örnek verilmektedir:

"Görüşmecilerin seçiminde herhangi bir yöntem uygulanmamış, Akyaka sokaklarında rastgele rastlanılan kişiler, araştırma hakkında kısaca bilgilendiril- miş ve onlara araştırmaya katılmak isteyip istemedikleri sorulmuştur. Görüşmeye katılabilmeleri için katılımcılarda, çalışmanın yerel toplum kavramına uygun olarak, tüm yıl Akyaka'da yaşıyor olmaları koşulu aranmıştır." (Çalışma 14)

Çalışmalar çeşitleme ölçütü açısından incelenirken; yöntemde, alanda, araştırmacıda veya teoride olmak üzere birden çok seçeneğin bir arada kullanılıp kullanılmadığına bakılmıştır. Buna göre 13 çalışmada çeşitleme kullanıldığ1 tespit edilmiştir. Bir çalışmada yöntemde farklı çeşitlerin nasıl kullanıldığı şu şekilde açıklanmıştır:

“...Bu amaç doğrultusunda araştırmada iki çeşit birincil veri toplama yöntemi kullanılmıştır. Anket uygulaması "nicel (kantitatif) araştırma yöntemi" olarak sayısal bilgilerin elde edilmesinde kullanılırken; mülâkat, katılımcı gözlemleri ve merkezi grup tartışmaları "nitel (kalitatif) araştırma yöntemleri" olarak konuyla ilgili bilgilerin elde edilmesinde kullanılmıştır." (Çalışma 31)

Bundan başka karşılaşılan diğer bir çeşitleme türü ise uygulama alanında çalışmanın farklı grupları kapsayacak şekilde gerçekleştirilmesidir. Bunu gösteren bir başka çalışmadan alınmış bir örnek şu şekildedir:

"Bulgularm farkl kaynaktan alınan veriler ile uyumuna bakılması bakımından araştırma üç grup (yerel halk, işletme sahipleri/yöneticileri, yerel yönetim) üzerinde yürütülmüştür." (Çalışma 25)

Katılımcıların dürüstlüğü ölçütü açısından yapılan değerlendirmede, çalışmaların 22 tanesinde, araştırmacılar katılımcıların verdikleri cevapların güvenirliliğini sağlamak için aldıkları önlemler hakkında herhangi bir bilgiye yer vermemişlerdir. Sadece dört çalışmada buna yönelik bilgiler olduğu ortaya çıkmıştır. Bu dört çalışmanın tamamı, 2011 yılından sonra yayınlanmıştır. Araştırmacıların, katılımcıların dürüstlüğü ile ilgili gerekli önlemleri almış olsalar dahi çalışmalarında bunları belirtmeye ihtiyaç duymamış olabilecek olmaları bu sonucun ortaya çıkmasında önemli bir etken olarak görülebilir. Her hâlükârda bu ölçütün kullanılmasının ve çalışmalarda belirtilmesinin öneminin son yıllarda anlaşılmaya başlandığı sonucu görülmektedir. Bu ölçüte yönelik bir uygulama şu sözlerle ifade edilmiştir: 
"Görüşmeler katıllmcuların uygun gördükleri saatlerde ve çalışma ofislerinde gerçekleştirilmiştir. ... Görüşmelerin etkin gerçekleştirilebilmesi için fiziki ve beşeri unsurlarm araştırmanın amacına uygunluğu sağlanmıştır. Görüşmeler sırasında katılımcılara yöneltilen sorulara verilecek yanitlarm sadece araştırma amacı ile kullanılacağı ve bu bulgular yorumlanırken herhangi bir şekilde isim / soy isim / işletme / kurum adının kullanılmayacağı ifade edilerek görüşmenin güven içinde gerçekleşmesi amaçlanmıştır." (Çalışma 22)

İncelenen çalışmaların hiçbirinde araştırmac1ların çalışmalarında kullandıkları soruların yinelenerek cevabın teyit edilmesine yönelik bir uygulama hakkında bilgiye ulaşılamamıştır. Bununla beraber yinelenen sorular ölçütünün anket gibi nicel çalışmalarda gerekli ve geçerli bir yöntem olmasına karşın, söz gelimi birebir mülâkat yapılan nitel çalışmalarda katılımcıları aptal yerine koyma şeklinde anlaşılacak olumsuz bir sonuca sebep olabileceği düşünülmelidir. Ayrıca zamanı kısıtlı olan katılımcılar sebebiyle araştırmacının soruları yinelemeyi tercih etmemiş olabileceği de göz önünde bulundurulmalıdır. Yedi adet çalışma ise doğası gereği katılımcının olmaması sebebiyle soru sorulmadığından, bu ölçüt bakımından değerlendirilememiştir.

Olumsuz vaka analizi ölçütünün değerlendirmesi yapılırken her çalışma içerisinde karşılaşılacak bir durum olmadığ 1 dikkate alınarak sadece olumsuz vaka olabilecek durumlarla karşılaştığı$\mathrm{n}$ belirten ya da karşılaştığına dair metni içerisinde kanıt bulunan yazarların çalışmaları değerlendirilmiş, diğer çalışmalar ise ölçülemez olarak sınıflandırılmıştır. Bu çerçevede toplam dört çalışmada olumsuz vaka analizine tabi tutulabilecek istisnai durumlara rastlanmış ancak bu çalışmalardan sadece bir tanesinde bu durumun irdelendiği görülmüştür. İlgili örnek, şu şekildedir:

"Genel olarak bakıldığında, yavaş şehir markasının yöre halks üzerinde genelde ekonomik ve kültürel anlamda faydası olduğunu dile getiren katılımciların oranı oldukça yüksek çıkmaktadır. Bununla birlikte iki katılımo, elde edilen faydadan öte, ortaya çıkan zararın daha fazla olduğunu düşünmektedir. Bu iki katılımcının vurgulamak istediği olumsuz durum, yaşanan gürültü kirliliğidir. Plajda yüksek sesli çalı- nan müzik, artan trafik ve düzenlenen ücretsiz halk konserlerinin ortaya çıkardığg gürültü burada etkili olmaktadır." (Çalışma 25)

Diğer çalışmalarda ise yazarların karşılaştıkları, şablonun dışında kalan durumları incelemek yerine kapsam dışı bıraktıkları görülmüş̧ür.

Uzman incelemesi ölçütü açısından yapılan değerlendirmede, çalışmaların sekiz tanesinde araştırmacılar uzman incelemesi yaptıklarını belirtirken, 23 çalışmada ise buna yönelik bir ifade bulunamamıştır. Öte yandan son iki yılda (20142015) yayınlanmış olan altı çalışmanın tamamında uzman incelemesi yapıldığına dair ifadeler bulunduğu dikkat çekmektedir. Bu ölçüte yönelik bir çalışmadan alınmış ifade şu şekildedir:

"Görüşme formu geliştirilirken uzman akademisyenler ve sektör temsilcileri ile bir araya gelinmiştir." (Çalışma 24)

Araştırmacinın yorumu ölçütü açısından yapılan değerlendirmede, çalışmaların hiçbirinde araştırmacıların yaptıkları çalışmayı çeşitli aşamalarda değerlendirdiklerini gösteren ifadeler kullandıkları görülmemiştir. Ancak; bir çalışmanın araştırmacı tarafından her aşamada değerlendirilmesi ve incelenmesinin yazım sürecinin kaçınılmaz bir aşaması olduğu düşünülebilir.

Araştırmacının geçmişi ve deneyimi ölçütü açısından yapılan değerlendirmede, çalışmaların sadece bir tanesinde, araştırmacı çalıştı̆̆ 1 alan hakkında deneyimi olduğunu belirtmiştir. 30 çalışmada ise araştırmacıların çalıştıkları alan hakkında deneyimleri olup olmadığı konusunda bilgiye rastlanamamıştır. Bu konu ilgili çalışmada şöyle ifade edilmektedir:

"Bu seçimde araştırmacıların bölge sinırları içinde yaşaması, dolayısılyla yöreyi daha önceden bilmesi, tanıması ve yöre hakkında deneyimlerinin olması etkili olmuştur. ... Diğger taraftan araştırmaciların durum çalışması yapılan çiftliklerle, daha önceki deneyimlerine kadar uzanan bir etkileşim süreci söz konusudur." (Çalışma 18)

Katılımcıların kontrolü ölçütü açısından yapılan değerlendirmede, çalışmaların dört tanesinde araştırmacıların yaptıkları uygulamanın son hâlini yayınlanmadan önce katılımcılara teyit ettirdikleri sonucu ortaya çıkmıştır. 22 çalışmada 
ise böyle bir uygulamaya rastlanamamıştır. $\mathrm{Bu}$ ölçütte dikkat çeken bir durum ise katılımcı sayısının az ve çalışmanın doğası gereği kimliğinin belli olduğu durumlarda bu ölçütün daha rahat uygulanabildiğidir. Nitekim özellikle rastgele seçilmiş turist veya yerel halk gibi katılımcilarla yapilan çalışmalarda anonimlik prensibi ön plânda olduğu için katılımcının iletişim bilgileri çoğunlukla alınmamaktadır. Bazı çalışmalar, doğası gereği katılımcı olmamasından dolayı bu ölçüt açısından ölçülememiştir. Katılımcı kontrolüne yönelik bir çalışmada geçen bir ifade şöyledir:

"Nihai olarak araştırmaya katılanlardan, araştırmanın bulguları konusunda görüs alınması da güvenilirliği arttırmaktadır. Bu doğrultuda bu çalışmada kendileri ile görüşülen şeflerden altısına tekrar ulaşılmış, araştırma sonucu elde edilen bulgular kendilerine anlatılmış ve görüşleri sorulmuştur. Bu süreç sonunda görü̧̧ü alınan şefler araştırma bulgularının kendi düşünme ve deneyimlerini yansıttığın belirtmişlerdir." (Çalışma 31)

Araştırmacı tarafından araştırılan olgunun kavramsal çerçevesi güvenirlik ve geçerlik ad1na yeterli düzeyde sunulmalıdır. Ancak sunulan kavramsal çerçevenin yeterli olup olmadığı her bir okuyucu açısından öznel olarak ayrı ayrı değerlendirilebilir. Bu yüzden araştırılan olgunun kavramsal çerçevesinin yeterliliği ölçütü bu çalışma içerisinde değerlendirmeye alınırken nesnellikten uzaklaşmamak için 'ölçülemez' olarak sınıflandırılmıştır.

Bulguların literatürle kıyaslanması ölçütü açısından yapılan değerlendirmede, 15 çalışmada araştırmacıların elde ettikleri sonuçları geçmiş çalışmalarla kıyasladıkları görülürken, çalışmaların 16'sında ise kiyaslamadıkları sonucu ortaya çıkmıştır. Özellikle 1990'lı yıllarda yapılmış olan dokuz nitel çalışmanın hiçbirinde bulguların alanyazınla kıyaslandığına dair bir ifadeye rastlanmamıştır. Bir çalışmadan bu ölçütle ilgili yapılan alıntı şu şekildedir:

“...Shah ve diğerlerinin (2006) görüşü ile benzer şekilde, müşteri merkezli işletmelerin, müşteri sadakati ile uzun dönemli kârlllık sağlayabileceğini belirten bir görüş ise şöyledir..." (Çalışma 19)

Aktarılabilirlik ana ölçütü kapsamında altı alt ölçüt yer almaktadır. Bu ölçütler açısından ince- lendiğinde çalışmaların 24 tanesinin alt ölçütlerin \%50'sinden fazlasını karşıladığı saptanmıştır. Araştırmacıların çalışmalarında temel ölçütler açısından en fazla aktarılabilirlik ölçütüne çalışmalarında yer verdikleri sonucu ortaya çıkmıştır. Ayrıca, 2007-2015 yılları arasında yayınlanan çalışmaların tamamında söz konusu ölçütlerin $\% 50$ 'sinden fazlasının karşılandığı görülmektedir.

Bu ölçütlerden ilkine göre, çalışmaların 20 tanesinde araştırmacılar verileri topladıkları kurum veya işletmelerin sayısını belirtirken, yedi çalışmada ise belirtmemişlerdir. Bazı çalışmalar ise araştırmada kurum veya işletme olmadığından "Ölçülemez" olarak sınıflandırılmıştır. Bazı çalışmalarda verilerin toplandığ kimlik bilgilerinin verildiği de tespit edilmiştir. Çalışmaya katılan kurum sayısının belirtilmesine dair bir örnek şu şekildedir:

“... Türkiye'ye yönelik tur düzenleyen 56 tur operatörünün seyahat rehberinden adresleri alınmıştır. ... tur kataloglarn istenmiş, bu isteğe 56 tur operatöründen 36'sı (\%64) olumlu cevap vermiştir." (Çalışma 3)

Araştırmacıların 16 çalışmada katılımcılar ile ilgili kısitları belirtirken, 15 'inde ise bunları belirtmediği sonucu ortaya çıkmıştır. Kısıtların belirtildiği çalışmalardan birinden yapılan ilgili bir alıntı şu şekildedir:

"Burada örneklem seçilirken sahada yaşanan problemler, araștırmanın temel tasarımının esnekleștirilmesine neden olmuştur. İçine girilen çeoreye araştırmacı olarak yabancı olunması, katılımcıların çekinceleri, özellikle Alman turistlerin çalı̧maya katılmak istememesi ve bu durumlarm anket yapılmasin gerekli kılacak sayının düşük olmasına neden olmuş, böylece çalışmada nitel bir analiz biçimi olarak gözatım (survey) tekniğgi kullanılmıştır." (Çalışma 17)

Araştırmacılar, 25 çalışmada uygulama alanına konu olan katılımc1/doküman vb. veri kaynaklarının sayısını belirtmişlerdir. Öte yandan altı çalışmada ise bu sayının belirtilmediği sonucu ortaya çıkmıştır. Bir çalışmadan katılımcı sayısının belirtilmesine yönelik alınmış bir ifade şu şekildedir:

"Araştırma, beş yıldızlı konaklama işletmelerinde görevli 10 yabancr genel müdür ve onlara bağhl olarak 
çalışan 27 Türk departman müdürleriyle gerçekleştirilmiştir." (Çalışma 26)

Araştırmacılar 29 çalışmada veri toplama yönteminin nasıl uygulandı̆̆ına dair bilgiye yer verirken, sadece iki çalışmada bu bilgiye rastlanamamıştır. Bununla ilgili çalışmalardan alınan bir örnek şu şekildedir:

"Bu işletmelerden merkezi İstanbul'da bulunan dördü ile birebir görü̈sülerek çalışılmıştır. Merkezi Kuşadası'nda bulunan bir işletme ise anket çalışmastna faks yolu ile katılmıştır." (Çalışma 7)

Araştırmacılar dokuz çalışmada uyguladıkları nitel araştırma yöntemlerinin uygulama süresi hakkında bilgiye yer verirken, 22 çalışmada bu bilgiye yer verilmemiştir. Bununla beraber yöntemin uygulama süresine dair bilgi verildiği tespit edilen dokuz çalışmanın tamamının 2008 yılından sonra yayınlanmış çalışmalar olduğu görülmüştür. Bir örnek ifade şu şekildedir:

“... her bir kişi için ortalama görüşme süresi, 15-60 dakika arasında değgişmiştir." (Çalışma 25)

Araştırmacılar 12 çalışmada verileri topladıkları zaman aralığı hakkında bilgiye yer verirken, 19 çalışmada ise böyle bir bilgiye yer verilmemiştir. Yöntemin uygulama süresi ölçütüne benzer bir şekilde, verinin toplandığ 1 zaman (tarih) aralığ1 bilgisinin çalışmalarda verilmesi 2008 yılından sonra görülmektedir. Bu tarihten önce yapılmış 15 çalışmanın hiçbirinde zaman aralığ 1 bilgisi yokken, bu tarihten sonra yapılan 16 çalışmanın 12 'sinde bu bilginin verildiği dikkat çekmektedir. Bu çalışmaların bir tanesinde verinin toplandığ̣ zaman aralığı kısaca şu şekilde aktarılmıştır:

"Görüşmelere 15.10.2011 tarihinde başlanmış ve 10.01.2012 tarihinde görüşmeler tamamlanmıştır." (Çalışma 20)

Tutarlılık ölçütü açısından değerlendirildiğinde, sadece iki alt ölçüt bulunmakla beraber 19902006 yılları arasında yayınlanmış 13 çalışmanın yedi tanesinde bu alt ölçütlere rastlanamamıştır. 2007-2015 yılları arasında yayınlanan çalışmaların tamamında ise söz konusu alt ölçütlerin en azından birinin karşılandığı görülmektedir.

Bunların içinden örtüşen yöntemlerin kullanılması ölçütü açısından yapılan değerlendirmede, sadece sekiz çalışmada örtüşen yöntemlerin kullanıldığı, 23 çalışmada ise tek yöntem üzerinden analizlerin yapıldığı sonucu ortaya çıkmıştır. Bir çalışmada örtüşen yöntemlerin nasıl kullanıld1ğına dair verilen bir ifade şu şekildedir:

"Alan araştırması kapsamında dizinin çekildiği yer olan Muğla'nın Bozüyük beldesine toplam üç gezi yapıld ve bu günlerde hem mülakat hem de bazı dizi sahnelerinin çekimine şahit olunarak yerinde gözlem gerçekleştirildi." (Çalışma 16)

Bir diğer ölçüte göre, 22 çalışmada tasarımının detaylıca tanımlandığ 1 yorumu yapılırken, dokuz çalışmada ise tasarımın detaylı bir şekilde belirtilmediği görüşü ortaya çıkmıştır.

Doğrulanabilirlik ana ölçütü altında dört alt ölçüt bulunmaktadır. Bu ölçütler açısından değerlendirildiğinde ise 1990-2006 yılları arasındaki çalışmaların sadece bir tanesinde alt ölçütlerin $\% 50$ 'sinden fazlasının karşılandığı görülürken, 2007-2015 yılları arasındaki 18 çalışmanın 15'inde alt ölçütlerin \%50'sinden fazlasının karşılandığı görülmüştür. Araştırmacıların diğer ölçütlerde olduğu gibi 2007-2015 yılları arasında doğrulanabilirlik ölçütüne de daha fazla önem verdikleri sonucu ortaya çıkmıştır.

Bunlardan ilk ölçüte göre, 15 çalışmada araştırmacının inanç ve varsayımlarına yer verildiği, 16 çalışmada ise bunun verilmediği sonucu ortaya çıkmıştır. Araştırmacının çalışmanın başında kendi görüşünü (inanç ve varsayımını) yansıttığ 1 düşünülen, bir referansa dayandırılmamış bir örnek şu şekilde verilebilir:

"Bu nitel çalışmada engellilerin turizm hizmetleri ile ilgili genel beklentilerinin derinlemesine değerlendirilmesi hedeflenmiştir. Ayrıca, bu çalışmanin engelli insanların turizm faaliyetlerine katılımı önündeki engellerle mücadele çalışmalarına ve bu alanda yaptlacak olan bilimsel nicel araştırmalarm alt yapısın oluşturmasına katkı sağlayacağı düşünülmektedir." (Çalışma 29)

Yapılan değerlendirmede, 12 çalışmada araştırma yönteminin sinırlılık ve potansiyel etkilerinin ne olacağına dair bilgilerin yer aldığı görülürken, 19 çalışmada ise buna yönelik bir ifadeye rastlanamamıştır. Bir çalışmadan bu ölçüte yönelik ifade şu şekilde alıntılanmıştır:

"Diğer taraftan bu çalışmada havalimanlarının web sitelerinde yer alan görsel metinler dikkate alınmış ve göstergebilimsel analize tabi tutulmuştur. Oysaki söz 
konusu havalimanlarında bulunarak gözlem yapmak ve/veya mekân görsellerine ilişkin veri toplamak ve bu görsel metinler üzerinden analiz yapmak daha uygun bir yol olabilirdi." (Çalışma 21)

Araştırmacılar 16 çalışmada uyguladıkları nitel araştırma yöntemleri hakkında açıklayıcı bilgiye yer verirken, 15 'inde ise buna değinmemişlerdir. 1990’1 y 1llarda yapılan çalışmalarda yönteme dair pek bir açıklama görülmüyorken, özellikle son üç yılda (2013-2015) yapılan 10 çalışmanın dokuz tanesinde yöntemin açıklanıyor oluşu dikkat çekmektedir. Bu konuda bilgi vermenin yine son dönemlerde üzerinde durulan bir tercih olduğu anlaşılmaktadır. İncelenen çalışmalardan yöntemin nasıl aktarıldığına dair verilebilecek bir örnek şu şekildedir:

“Odak Grup Çalışması, konu ile ilgisi uzmanlık derecesinde olan bir yürütücü kontrolünde ve beyin firtınası şeklinde tartışmalara da olanak sunan bir açık uçlu soru-cevap düzleminde gerçekleşmektedir. Katılımo sayısı genellikle 6-8 arasıdır (Walle 2001)." (Çalışma 15)

Yapılan çalışmaların sadece bir tanesinde araştırma sürecini detaylıca aktaran bir diyagramın kullanıldığ görülmüştür. 30 çalışmada ise bu süreci gösteren bir diyagram veya benzeri bir şekle rastlanamamıştır. İlgili çalışmada yer alan araştırma süreci diyagramı örneği Şekil 3'te gösterilmektedir. Görselin kalitesini yüksek tutmak ve okuyucunun örneği daha rahat inceleyebilmesini sağlamak için doğrudan alıntı yapılmamış, ilgili diyagram aslına uygun olarak yeniden hazırlanmıştır.

\section{TARTIŞMA VE SONUÇ}

Yapılan bu araştırmada, Anatolia Turizm Araştırmaları Dergisi'nde 1990-2006 yılları arasında yayınlanan çalışmalar ile 2007 'den sonrakiler arasında güvenirlik ve geçerlik modeli ölçütlerinin karşılanma düzeyleri açısından farklılıklar olduğu, 2007 yılından sonra yayınlanan çalışmalarda bu ölçütlerin kullanılma oranının ortalama olarak \%21'den \%54'a çıktığı tespit edilmiştir.

Araştırmanın bulguları 1şığında, 1990-2006 yılları arasında toplam 13 çalışma, 2007-2015 yılları arasında ise toplam 18 çalışma olduğu tespit edilmiştir. Özellikle 2013-2015 yılları arasındaki kısa sayılabilecek bir zaman aralığında 10 adet nitel çalışmanın olması dikkat çekicidir. Bununla birlikte 2011-2015 yılları arasındaki bazı çalışmalarda, güvenirlik ve geçerlik ölçütlerine, ilgili ölçütlerin ne oldukları ve neden kullanıldıkları hakkında açıklamalara yer verilerek, teorik yönden de vurgu yapıldığ süreçte güvenirlik ve geçerlik ölçütlerine özen gösterdiklerini bu ölçütleri tanımlayarak, bu ölçütlere yönelik atıflar kullanarak ve bu ölçütleri kendi çalışmalarında nasıl gerçekleştirdiklerini okuyucu ile paylaşarak vurgulamaktadırlar.

Bu çalışmada ele alınmış olan güvenirlik ve geçerlik ölçütleri Shenton (2004) tarafından özellikle Guba'ya (1981) dayandırılarak oluşturmuş olup nitel araştırmalarda uygulanması ve ifade edilmesi gereken önemli stratejileri içermektedir. Buna karşın 1990-2006 yılları arasında yayınlanan 13 nitel çalışmanın hiçbirinde güvenirlik ve geçerliği ölçmek için oluşturulan 26 ölçütün \%50'sinden fazlasının karşılanmadığ saptanmıştır. 2007-2015 yılları arasında ise incelenen 18 çalışmanın 12'sinin söz konusu ölçütlerin \%50'sinden fazlasını karşıladığı görülmektedir. 19902006 yılları arasında yayınlanan çalışmaların ortalama olarak 26 ölçütün 5,4 (\%21) tanesini karşıladığı görülürken, 2007-2015 yılları arasındaki çalışmalarda ortalama olarak 14 (\%54) ölçütün karşılanmakta olması dikkat çekmektedir.

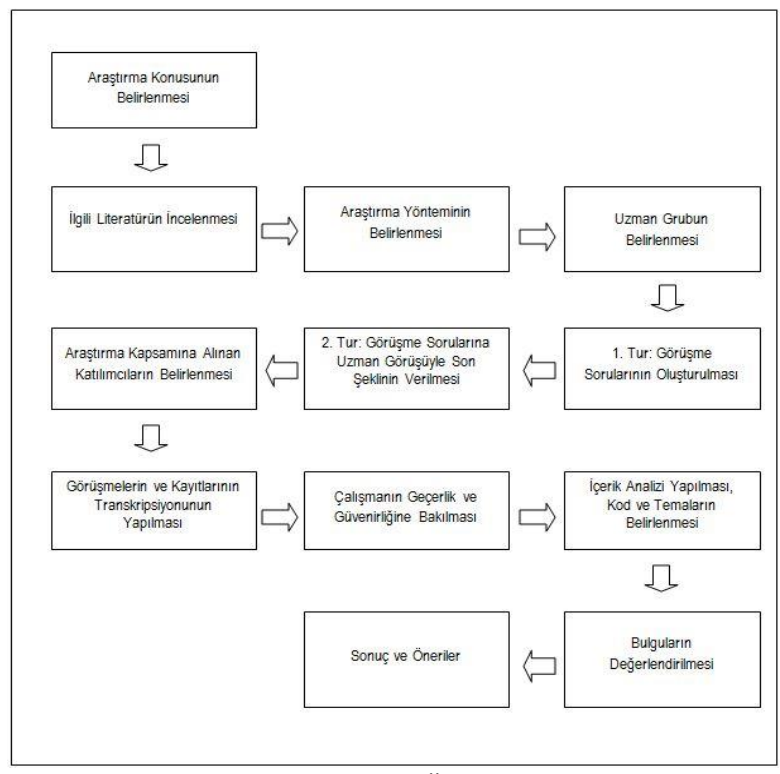

Şekil 3. Araştırma Süreci Diyagramı Örneği (Çalışma 30) 
İnandırıcılık ölçütü altında yer alan "uygulama alanın tanıma", "katılımcıların dürüstlüğ̈̈̈", "yinelenen sorular", "olumsuz vaka analizi", "uzman incelemesi", "araştırmactnın yorumu", "araştırmactnın geçmiş ve deneyimi", "katılımcuların kontrolü"; aktarılabilirlik ölçütü altında "yöntemin uygulanma süresi"; tutarlılık ölçütü altında "örtüşen yöntemlerin kullanılması" ve doğrulanabilirlik ölçütü kapsamında "diyagram" alt ölçütlerine yönelik ifade sıklığının oldukça az olduğu yapılan incelemelerde ortaya çıkmıştır. Özellikle "olumsuz vaka analizi" ölçütü çerçevesinde yapılan değerlendirmede, yazarların bir kısmının çalışmaları esnasında karşılaştıkları istisnai durumları irdelemek yerine kapsam dışı bırakmış olmaları da dikkat çekici bir bulgudur. Çalışmanın aktarılabilirlik ve doğrulanabilirlik başlıkları altında yer alan alt ölçütlerine 1990-2006 yılları arasındaki çalışmalarda çok nadiren değinilirken, 2007-2015 yılları arasında yapılan araştırmaların neredeyse tamamında bu ölçütler ile ilgili ayrıntılı bilgiler veril- diği saptanmıştır. Yapılan değerlendirmede, sadece bir çalışmada araştırmacıların elde ettikleri bulgular ile diyagram oluşturdukları, 30 tanesinde ise bunun yapılmadığı görülmüştür.

Yapılan incelemelerde göze çarpan bir diğer husus ise ele alınan çalışmalarda araştırmacıların herhangi bir gömülü kuramı tespit etmeye yönelmemiş olmalarıdır. Buradan çalışmaları yapanların nitel ve nicel araştırmaların temel yapılarını tam olarak anlayıp anlamadıkları veya karıştırdıkları sonucu çıkabilir. Bazı yazarların yöntem seçimlerini açıklarken örneklemin azlığının nicel bir çalışmaya imkân tanımadığ neldiklerini ifade ettikleri görülmüştür. Oysaki nitel araştırmalara yönelimin sebebi sadece örneklemin sınırlı olması değildir. Nitel araştırmalar nicel araştırmaların alternatifleri değildirler, bununla birlikte nicel araştırmalar da nitel araştırmaların alternatifleri değildirler. Her ikisinin kullanım amaçları tamamen alana özgüdür. Nitel araştırmaların genel olarak gömülü kuramı

Tablo 4. Nitel Araştırmalarda Geçerlik ve Güvenirlik Sağlamak İçin Alınması Gereken Önlemler

\begin{tabular}{|c|c|c|c|}
\hline İnandırıcılık & Aktarılabilirlik & Tutarlıık & Doğrulanabilirlik \\
\hline $\begin{array}{l}\text { Yöntem, araşıımanın niteliğine göre } \\
\text { geliştrilmeli ve kurgulanmalı }\end{array}$ & $\begin{array}{l}\text { Varsa uygulama yapılan kurum } \\
\text { veya işletme sayısı belirtilmeli }\end{array}$ & $\begin{array}{c}\text { İmkân dâhilinde ise aynı } \\
\text { uygulama alanına farklı yöntemler } \\
\text { uygulanmalı }\end{array}$ & İmkân dâhilindeyse üçleme yapılmalı \\
\hline $\begin{array}{l}\text { Uygulama yapılacak alan önceden } \\
\text { tanınmalı/araştııımalı }\end{array}$ & $\begin{array}{l}\text { Varsa katılımcılarla ilgili kısıtlar } \\
\text { net bir şekilde belirtilmeli }\end{array}$ & $\begin{array}{l}\text { Çalışmanın tekrarlanabilmesi için } \\
\text { süreçler ayrıntılı bir şekilde } \\
\text { belirtilmeli }\end{array}$ & $\begin{array}{l}\text { Araştırmacı, araştırma ile ilgili } \\
\text { inanç ve varsayımlarını belirtmeli }\end{array}$ \\
\hline $\begin{array}{l}\text { Uygulama alanı ve/veya katılımcıların } \\
\text { seçiminde tarafsız olunmalı }\end{array}$ & $\begin{array}{l}\text { Varsa uygulama yapılan katılımcı } \\
\text { veya doküman vs. sayısı belirtilmeli }\end{array}$ & & $\begin{array}{l}\text { Kullanılan yöntemin sınırılıkları ve } \\
\text { potansiyel etkileri belirtilmeli }\end{array}$ \\
\hline İmkân dâhilindeyse üçleme yapıImalı & $\begin{array}{l}\text { Veri toplama yöntemlerinin } \\
\text { nasıl uygulandığı belirtilmeli }\end{array}$ & & $\begin{array}{c}\text { Kullanılan yöntem teorik olarak } \\
\text { açıklanmalı }\end{array}$ \\
\hline $\begin{array}{l}\text { Katııımcıların dürüstlüğünü sağlamak } \\
\text { için önlemler alınmalı }\end{array}$ & $\begin{array}{l}\text { Veri toplama seanslarının ne kadar } \\
\text { sürdüğü not edilmeli ve belirtilmeli }\end{array}$ & & $\begin{array}{c}\text { Araştırma süreci üzerinden şematik bir } \\
\text { model oluşturulmalı }\end{array}$ \\
\hline $\begin{array}{l}\text { Cevapların doğruluğu sorular } \\
\text { tekrarlanarak teyit edilmeli }\end{array}$ & $\begin{array}{l}\text { Uygulamanın hangi tarihte veya } \\
\text { tarih aralığında gerçekleştirildiği } \\
\text { belirtilmeli }\end{array}$ & & \\
\hline \multicolumn{4}{|l|}{$\begin{array}{l}\text { Süreç içinde ortaya çıkan eksiklikler } \\
\text { ve hatalar giderilmeli }\end{array}$} \\
\hline \multicolumn{4}{|l|}{$\begin{array}{l}\text { Araştırma sürecinde uzman görüşüne } \\
\text { başvurulmalı }\end{array}$} \\
\hline \multicolumn{4}{|l|}{$\begin{array}{l}\text { Araştırmanın her aşaması tekrar tekrar } \\
\text { gözden geçirilmeli }\end{array}$} \\
\hline \multicolumn{4}{|l|}{$\begin{array}{l}\text { Araştırmacının konu ile ilgili geçmişten } \\
\text { bir bağı varsa belirtilmeli }\end{array}$} \\
\hline \multicolumn{4}{|l|}{$\begin{array}{l}\text { Uygulama aşamasından sonra bulgular } \\
\text { katılımclara teyit ettirilmeli }\end{array}$} \\
\hline \multicolumn{4}{|l|}{$\begin{array}{c}\text { Araştırma konusu detaylı bir şekilde } \\
\text { verilmeli }\end{array}$} \\
\hline Bulgular alanyazınla kıyaslanmalı & & & \\
\hline
\end{tabular}


Tablo 5. Yazarların Kendi Çalışmalarına Yönelik Değerlendirmesi

\begin{tabular}{|c|c|c|}
\hline \multirow{14}{*}{ 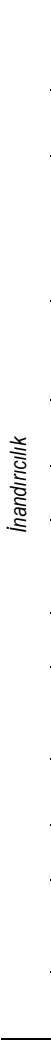 } & $\begin{array}{l}\text { Uygun Yöntem Kullanımı } \\
\text { ve Uygulama }\end{array}$ & $\begin{array}{l}\text { Çalışmanın amacı nitel araştırmalarda güvenirlik ve geçerlik modeli ölçütlerinin ne derecede kullanıldığının tespit edilmesidir. Bunun için seçilen } \\
\text { örneklemde yer alan nitel çalışmalar içerik analizi yöntemine tabi tutularak ölçütlerin tek tek tespit edilmesi amaç̧anmıştır. Bu çerçevede araşıırmada } \\
\text { amaç ve yöntem tutarlıı̆ı olduğu söylenebilir. }\end{array}$ \\
\hline & $\begin{array}{l}\text { Uygulama Alanını } \\
\text { Tanımak }\end{array}$ & $\begin{array}{l}\text { Çalışma bir doküman analizi niteliğinde olduğu ve örneklemesinde kişiler yer almadığı veya gözlem yapılmadığı için bu strateji bu çalışma içerisinde } \\
\text { uygulanabilir nitelikte değildir. }\end{array}$ \\
\hline & $\begin{array}{l}\text { Rastlantısal Örneklem } \\
\text { Seçimi }\end{array}$ & $\begin{array}{l}\text { Bu çalışmada yazarlar, çalışmanın yapısı ve amaçları gereği rastlantısal örneklem seçiminden daha verimli olacağını düşündükleri amaçlı örneklem } \\
\text { seçimine yönelmişlerdir. Çalışmanın alanı olarak Anatolia Turizm Araşıımaları Dergisinin seçilme nedeni turizm alanında en uzun süredir kesintisiz } \\
\text { yayın yapan dergi olarak süreçsel bir değerlendirmeye en uygun olan dergi olmasıdır. İncelenen makaleler ise dergide yayınlanan tüm nitel makaleler } \\
\text { olduğu için örnekleme yapıımayıp tüm eserler değerlendirilmiştir. Bu çerçevede bu çalışmanın yazarlarının örneklem seçimini belirli ölçütler } \\
\text { çerçevesinde ve önyargılardan uzak durarak yaptıkları ifade edilebilmektedir. }\end{array}$ \\
\hline & Çeşitleme & $\begin{array}{l}\text { Çalışmada araştırmacıda çeşitleme yapıımıştır. İncelenen tüm çalışmalar yedi farklı araştırmacı tarafından öncelikle ayrı ayrı değerlendirilmiş ve notlar } \\
\text { alınmıştır. Ardından tüm araştırmacılar bir araya gelerek görüş birliğine varana dek ölçütleri değerlendirmişlerdir. }\end{array}$ \\
\hline & & Çalışmada veri kaynağı ve yöntemde çeşitleme yapıımamışır. \\
\hline & Katılımcıların Dürüstlüğü & $\begin{array}{l}\text { Çalışma bir doküman incelemesi olduğu ve örneklemi içerisinde katılımcılar yer almadığı için katılımcıların dürüstlüğü ölçütü uygulanabilir nitelikte } \\
\text { değildir. }\end{array}$ \\
\hline & Yinelenen Sorular & Çalışma bir doküman incelemesi olduğu ve örneklemi içerisinde katılımcılar yer almadığı için yinelenen sorular ölçütü uygulanabilir nitelikte değildir. \\
\hline & Olumsuz Vaka Analizi & $\begin{array}{l}\text { Çalışmada doküman incelemesi esnasında ortaya çıkan farklı yapılar veya ifadeler, araştırmacıların ölçütlere yönelik algılarını ve ölçütleri } \\
\text { değerlendirme yöntemlerini değiştirmiş veya geliş̧irmiştir. Bu bağlamda araşıımacılar dokümanların değerlendirilmesi sürecinde, gelişen yöntemler } \\
\text { ışığında, iki kez geriye dönük olarak ölçütleri yeniden değerlendirmiştir. }\end{array}$ \\
\hline & Uzman İncelemesi & Çalışmanın her aşamasında nitel araştırmalar konusunda deneyimli akademisyenlerin görüş ve önerilerinden yararlanılmıştır. \\
\hline & Araştırmacının Yorumu & $\begin{array}{l}\text { Çalışmanın her aşamasında süreçler araştırmacıların tümü tarafından tekrar tekrar gözden geçirilerek ilerlenmiştir. Yapılan toplantılarda bu öz } \\
\text { değerlendirmeler esnasında göze çarpan hususlar üzerine tartı̧̧ımış̧ır. Gerekli görülen durumlarda değişiklikler yapılımış ve çalışma güncellenerek } \\
\text { devam etmiştir. }\end{array}$ \\
\hline & $\begin{array}{l}\text { Araştırmacının Geçmiş ve } \\
\text { Deneyimi }\end{array}$ & $\begin{array}{l}\text { Araştırmacılar ile ilgili bilgilere yöntem kısmında yer verilmiştir. Ayrıca araşıırmacılardan birinin örneklemin alındığı dergide editörlük yapmakta olduğu } \\
\text { bilgisi araştırma konusuna yakınlık gösterdiği için okuyucuyla paylaşılmışır. }\end{array}$ \\
\hline & Katılımcıların Kontrolü & Çalışma bir doküman incelemesi olduğu ve örneklemi içerisinde katılımcılar yer almadığı için kattımcıların kontrolü ölçütü uygulanabilir nitelikte değildir. \\
\hline & $\begin{array}{l}\text { Araştırılan Olgunun } \\
\text { Kavramsal Çerçevesinin } \\
\text { Yeterliliği }\end{array}$ & $\begin{array}{l}\text { Çalışmanın kavramsal çerçevesi oluşturulurken ilgili yazın araştımacıların tamamı tarafından incelenmiş, nitel araştırmalarda güvenirlik ve geçerlik } \\
\text { üzerine çalışmalar yapan ve katkı sağlayan bütün önemli isimlere yer verilmeye çalış̧ıışır. }\end{array}$ \\
\hline & $\begin{array}{l}\text { Bulguların Literatürle } \\
\text { Kıyaslanması }\end{array}$ & Alanyazında buna benzer bir çalışma ile karşılaşı|madığından bulguları kıyaslamak mümkün olmamıştır. \\
\hline \multirow{6}{*}{ 竞 } & $\begin{array}{l}\text { Kurum İşletme Sayısının } \\
\text { Belirtilmesi }\end{array}$ & $\begin{array}{l}\text { Çalışma bir doküman incelemesi olduğu ve örneklemi içerisinde kurum veya işletmeler yer almadığı için kurum işletme sayısının belirtilmesi ölçütü } \\
\text { uygulanabilir nitelikte değildir. }\end{array}$ \\
\hline & Katilımcılarla İlgili Kısıtlar & $\begin{array}{l}\text { Çalışma bir doküman incelemesi olduğu için bu ölçütte katılımcı yerine doküman seçimiyle ilgili kısıtlar söz konusudur. İlgili kısıtlara yöntem kısmında } \\
\text { yer verilmiştir. }\end{array}$ \\
\hline & Katılımcı Sayısı & Çalışma bir doküman incelemesi olduğu için bu ölçütte katııımcı yerine doküman sayısına yöntem kısmında yer verilmiştir. \\
\hline & $\begin{array}{l}\text { Veri Toplama } \\
\text { Yöntemlerinin Uygulanışı }\end{array}$ & Çalışmanın yöntem bölümünde veri toplama yöntemlerinin nasıl uygulandığı detaylıca aktarımıı̧tır. \\
\hline & $\begin{array}{l}\text { Yöntemin Uygulama } \\
\text { Süresi }\end{array}$ & Çalışmanın yöntem bölümünde doküman inceleme ve analiz aşamalarına ayrılan süreler detaylıca belirtilmiş̧tir. \\
\hline & $\begin{array}{l}\text { Verinin Toplandığı Zaman } \\
\text { Aralığı }\end{array}$ & Çalışmanın yöntem bölümünde verilerin toplandığı zaman aralığı aktarılmıştır. \\
\hline \multirow{2}{*}{ 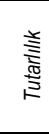 } & $\begin{array}{l}\text { Örtüşen Yöntemlerin } \\
\text { Kullanılması }\end{array}$ & Çalışmada tek bir yöntem kullanıldığı için bu ölçüt yerine getirilememiştir. \\
\hline & $\begin{array}{l}\text { Çalışma Tasarımının } \\
\text { Detaylıca Tanımlanması }\end{array}$ & $\begin{array}{l}\text { Yöntem kısmında araştırmanın süreçleri ile ilgili detaylıca açıklama yapııp aynı zamanda daha iyi takip edilebilmesi için tablo hâline getirilerek okuyucu } \\
\text { ile paylaşılışıır. }\end{array}$ \\
\hline \multirow{5}{*}{ 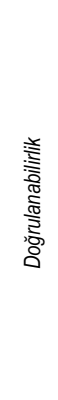 } & Çeşitleme & $\begin{array}{l}\text { Bu ölçüt hem inandırıcilık hem de doğrulanabilirlik temel ölçütleri altında yer almaktadır. Bu ölçütün çalışmada uygulanma durumuyla ilgili bilgi } \\
\text { inandırıclık kısmında verilmiştir. }\end{array}$ \\
\hline & $\begin{array}{l}\text { Araşıtımacının İnanç ve } \\
\text { Varsayımları }\end{array}$ & $\begin{array}{l}\text { Alanyazında benzer özellikte bir çalışmaya rastlanmadığından bu alanda önceden elde edilmiş sonuçlar da bulunmamaktadır. Bu sebeple çalışmanın } \\
\text { başlangııında araştırmacıların ne tür bulgular çıkacağına dair güçlü bir fikirleri oluşmamıştır. Çalışma keşifsel bir nitelik taşımakta olup içerisinde } \\
\text { araştırmacıların çalışmadan çıkacak sonuçlara dair beklentilerine yer verilmemiştir }\end{array}$ \\
\hline & $\begin{array}{l}\text { Yöntemin Sınırlılık ve } \\
\text { Potansiyel Etkileri }\end{array}$ & $\begin{array}{l}\text { Yöntemin sınıllııklarına ve potansiyel etkilerine dair bilgilere "çalışmanın sınırlııkları ve gelecekte yapılabilecek çalışmalara yönelik öneriler" kısmında } \\
\text { yer verilmiştir. }\end{array}$ \\
\hline & $\begin{array}{l}\text { Yöntemin Derinlemesine } \\
\text { Aktarıması }\end{array}$ & $\begin{array}{l}\text { Çalışmada seçilen yöntem, yöntemin uygulanışı, süreçleri, sınııllık ve potansiyel etkileri gibi unsurlara dair detaylı bilgilere yöntem ve sonuç } \\
\text { kısımlarında yer verilmişţr. }\end{array}$ \\
\hline & Diyagram & $\begin{array}{l}\text { Çalışmanın süreçlerine dair anlaşılırlı̆ı artıımak için hazırlanmış ve yöntem kısmında yer almakta olan "Araştırma Süreci" isimli şekil bir diyagram } \\
\text { örneğidir. }\end{array}$ \\
\hline
\end{tabular}


ortaya çıkarmaları (örneklemden bağımsız), nicel araştırmaların ise ortaya konulan bu kuramların (örnekleme bağımlı) genellenmesi ve test edilmesinde kullanılması daha güvenilir ve geçerli sonuçlar verecektir.

\section{ÇALIŞMANIN SINIRLILIKLARI VE GELECEKTE YAPILABILECEK ÇALIŞMALARA YÖNELIK ÖNERILER}

$\mathrm{Bu}$ araştırmada nitel araştırmalarda güvenirlik ve geçerlik ölçütleri olarak sadece Shenton'ın (2004) Guba'ya (1981) dayandırarak derlemiş olduğu ölçütlerin baz alınarak çalışmaların analiz edilmesi bu çalışmanın temel sınırlılığını oluşturmaktadır. Bir diğer sınırlılık ise araştırmada sadece Anatolia Turizm Araştırmaları Dergisi'nde yayınlanan nitel çalışmaların incelenmiş olmasıdır. Ortaya çıkan bulguların turizm alanında yayınlanan diğer dergilerdeki nitel çalışmalar ile karşılaştırılarak analiz edilmesi daha sağlıklı sonuçlara ulaşılmasını sağlayacaktır. Yöntem açısından bakıldığında ise incelenen makalelerin içerik analizine tabi tutulması üzerinden sonuçlara ulaşılmaya çalışılmıştır. Ancak bu çalışmaların yazarlarıyla görüşülmemiş ve çalışmalarında bu ölçütleri ne şekillerde ele aldıkları kendilerinden teyit edilmemiştir. Bu çerçevede bu eksiklik seçilen yöntemin bir kısıtı olarak kabul edilebilir. Bu açıdan da gelecekte yapilacak benzer şekilde kurgulanmış doküman incelemelerinin yazarların da görüşlerinin dâhil edilebileceği yöntemlerle zenginleştirilmesi bu alanda daha derinlemesine ve kapsamlı bulgular elde edilmesine imkân tanıyacaktır. Çalışma 1şığında, araştırmacılara gelecekteki nitel çalışmalarda yol göstermek amacıyla Tablo 4'tekine uygun bir kontrol süreci izlemeleri önerilebilir. Buna ek olarak bu çalışmanın yazarlarının kendi çalışmaları üzerine güvenilirlik ve geçerlik modeli ölçütleri çerçevesinde yaptıkları değerlendirmelere, okuyuculara yol gösterebilmek ve yardımcı olabilmek için Tablo 5'te yer verilmiştir.

\section{KAYNAKÇA}

Anatolia Turizm Araştırmaları Dergisi (2016). Hakem Denetimli Makaleler. http://www.anatoliajournal.com/ atad/?sayfa=anasayfaElang=tr, Erişim Tarihi: 30 Kasım 2015-05 Şubat 2016.
Angen, M. J. (2000). Evaluating Interpretive Inquiry: Reviewing the Validity Debate and Openning the Dialogue, Qualitative Health Research, 10: 378- 395.

Berg, B. L. (2000). Qualitative Research Methods for The Social Science. Boston, MA: Pearson.

Brink, H. I. L. (1993). Validity and Reliability in Qualitative Research, Curationis, 16 (2): 35-38.

Büyüköztürk, Ş. (2007). Sosyal Bilimler için Veri Analizi El Kitabl. Ankara: Pegem Yayıncilık.

Carlson, J. A. (2010). Avoiding Traps in Member Checking, The Qualitative Report, 15 (5): 1102- 1113.

Charles, C. M. (1995). Introduction to Educational Research. San Diego: Longman.

Creswell, J. W. (1998). Qualitative Inquiry and Research Design: Choosing Among the Five Traditions. Thousand Oaks, CA: Sage.

Creswell, J. W. (2003). Research Design: Qualitative, Quantitative and Mixed Methods Approaches. Thousand Oaks, CA: Sage.

Creswell, J. W. ve Miller, D. L. (2000). Determining Validity in Qualitative Inquiry, Theory into Practice, 39 (3): 124-130.

Curtin, M. ve Fossey, E. (2007) Appraising the Trustworthiness of Qualitative Studies: Guidelines for Occupational Therapists, Australian Occupational Therapy Journal, 54: 88- 94 .

Daymon, C. ve Holloway, I. (2003). Qualitative Research Methods in Public Relations and Marketing Communications. Londra: Routledge.

Decrop, A. (1999). Triangulation in Qualitative Tourism Research, Tourism Management, 20: 157- 161.

Denscombe, M. (2010). The Good Research Guide for Small-Scale Social Research Projects. Berkshire: Open University Yayınları.

Devers, K. J. (1999). How Will We Know “Good" Qualitative Research When We See It? Beginning the Dialogue in Health Services Research, HSR: Health Services Research, 34 (5): 1153- 1188

Eisner, E. W. (1991). The Enlightened Eye: Qualitative Inquiry and the Enhancement of Educational Practice. New York: Macmillan.

Elliott, R., Fischer, C. T. ve Rennie, D. L. (1999). Evolving Guidelines for Publication of Qualitative Research Studies in Psychology and Related Fields, British Journal of Clinical Psychology, 38: 215- 229.

Erlandson, D. A., Harris, E. L., Skipper, B. L. ve Allen, S. T. (1993). Doing Naturalistic Inquiry: A Guide to Methods. Beverly Hills, CA: Sage.

Firestone, W. A. (1993). Alternative Arguments for Generalizing from Data as Applied to Qualitative Research, Educational Researcher, 22 (4): 16- 23.

Fontana, A. ve Frey, J. H. (2005) Narrative Inquiry. İçinde Norman K. Denzin ve Yvonna S. Lincoln (Editörler) The Sage Handbook of Qualitative Research, (ss. 651-679). Londra: Sage Yayınları.

Golafshani, N. (2003). Understanding Reliability and Validity in Qualitative Research, The Qualitative Report, 8 (4): 597-606. 
Guba, E. G. (1981). Criteria for Assessing the Trustworthiness of Naturalistic Inquiries, Educational Communication and Technology: A Journal of Theory, Research, and Development, 29 (2): 75- 91.

Healy, M. ve Perry, C. (2000). Comprehensive Criteria to Judge Validity and Reliability of Qualitative Research within the Realism Paradigm, Qualitative Market Research: An International Journal, 3 (3): 118- 126.

Hoepfl, M. C. (1997). Choosing Qualitative Research: A Primer for Technology Education Researchers, Journal of Technology Education, 9 (1): 47- 63.

Horsburgh, D. (2003). Evaluation of Qualitative Research, Journal of Clinical Nursing, 12 (2): 307-12.

Kirk, J. ve Miller, M. L. (1986). Reliability and Validity in Qualitative Research. Beverly Hills: Sage Yayınları.

Kornbluh, M. (2015). Combatting Challenges to Establishing Trustworthiness in Qualitative Research, Qualitative Research in Psychology, 12 (4): 397- 414.

Kozak, M. (2014). Bilimsel Araştırma: Tasarım, Yazım ve Yayım Teknikleri. Ankara: Detay Yayıncilı.

Krefting, L. (1991). Rigor in Qualitative Research: The Assessment of Trustworthiness, The American Journal of Occupational Theraphy, 45 (3): 214- 222.

Kvale, S. (1995). The Social Construction of Validity, Qualitative Inquiry, 1 (1): 19- 40

Li, D. (2004). Trustworthiness of Think-Aloud Protocols in the Study of Translation Process, International Journal of Applied Linguistics, 14 (3): 301- 313.

Lietz, C. A., Langer, C. L. ve Furman, R. (2006). Establishing Trustworthiness in Qualitative Research in Social Work Implications From a Study Regarding Spirituality, Qualitative Social Work, 5 (4): 441- 458.

Lincoln, Y. S. ve Guba, E. G. (1985). Naturalistic Inquiry. Beverly Hills: Sage Yayınları.

Marvasti, A. B. (2004). Qualitative Research in Sociology. Londra: Sage Yayınları.

Maxwell, J. A. (1992). Understanding and Validity in Qualitative Research, Harward Educational Review, 62 (3): 279300.

Merriam, S. (1995). What Can You Tell From An N of 1 ?: Issues of Validity and Reliability in Qualitative Research, PAACE Journal of Lifelong Learning, 4: 50- 60.

Merriam S. B. (2013). Nitel Araştırma (Çev. S. Turan). Ankara: Nobel Akademik Yayıncilı.

Miles, M. B. ve Huberman, A. M. (1994). Qualitative Data Analysis. C.A: Sage Yayınları.

Morse, J. M., Barrett, M., Mayan, M., Olson, K. ve Spiers, J. (2002). Verification Strategies for Establishing Reliability and Validity in Qualitative Research, International Journal of Qualitative Methods, 1 (2): 13- 22.
Padgett, D. K. (1998). Qualitative Methods in Social Work: Challenges and Rewards. Londra: Sage Yayınları.

Patton, M. Q. (1999). Enhancing the Quality and Credibility of Qualitative Analysis, Health Services Research, 34 (5):1189- 1208

Patton, M. Q. (2002). Qualitative Research ve Evaluation Methods. John Wiley \& Sons.

Payton, O. D. (1979). Research: The Validalion of Clinical Practice. Philadelphia: F. A. Davis.

Rapport, F., Clement, C., Doel, M. A. ve Hutchings, H. A. (2015). Qualitative Research and Its Methods in Epilepsy: Contributing to an Understanding of Patients' Lived Experiences of the Disease, Epilepsy \& Behavior, 45: 94- 100.

Sekaran, U. (2003). Research Methods For Business A Skill Building Appproach. John Wiley \& Sons.

Shenton, A. K. (2004). Strategies for Ensuring Trustworthiness in Qualitative Research Projects, Education for Information, 22: 63-75.

Sinkovics, R. R., Penz, E. ve Ghauri, P. N. (2008). Enhancing the Trustworthiness of Qualitative Research in International Business, Management International Review, 48 (6): 689- 714 .

Stenbacka, C. (2001). Qualitative Research Requires Quality Concepts of Its Own, Management Decision, 39 (7): 551556.

Taylor, P. ve Wallace, J. (2007). Contemporary Qualitative Research: Exemplars for Science, Mathematics and Technology Educators. Dortrecht, The Netherlands: Springer.

Thomas, E. ve Magilvy, J. K. (2011). Qualitative Rigor or Research Validity in Qualitative Research, Journal for Specialists in Pediatric Nursing, 16: 151- 155.

Twycross, A. ve Shields, L. (2005). Validity and reliability What's It All About? Part 3 Issues Relating to Qualitative Studies, Paediatric Nursing, 17 (1): 36- 36.

Yıldırım, A. ve Şimşek, H. (2013). Sosyal Bilimlerde Nitel Araştırma Yöntemleri. Ankara: Seçkin Yayıncılık.

Whittemore, R., Chase, S. K. ve Mandle, C. L. (2001). Validity in Qualitative Research, Qualitative Health Research, 11 (4): 522-537.

Wiersma, W. ve Jurs, S. G. (2005). Research Methods in Education: An Introduction. Boston: Pearson Education.

Williams, E. N. ve Morrow, S. L. (2009). Achieving Trustworthiness in Qualitative Research: A Pan-Paradigmatic Perspective, Psychotherapy Research, 19 (4-5): 576- 582.

Wolcott, H. F. (1990). On Seeking -and Rejecting- Validity in Qualitative Research. İçinde E. W. Eisner ve A. Peshkin (Editörler) Qualitative Inquiry in Education: The Continuing Debate (ss. 121-152). New York: Teachers College Yayınları. 

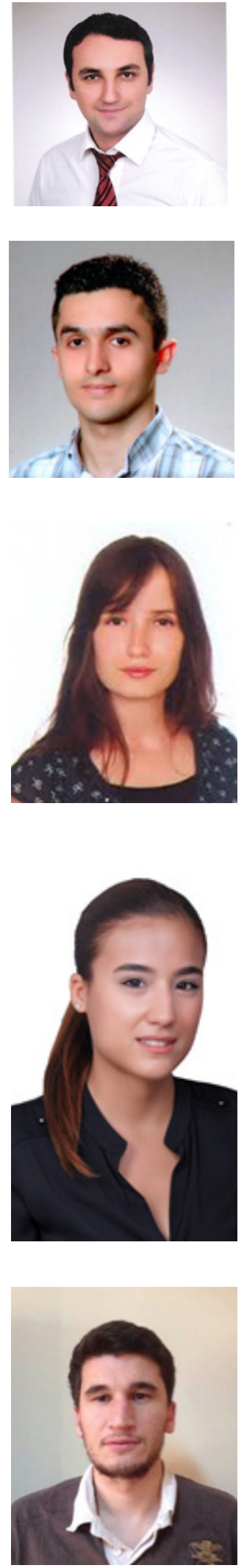

\section{Sinan ŞENER}

Dokuz Eylül Üniversitesi, İşletme Fakültesi Turizm İşletmeciliği Bölümü'nden 2012 yılında mezun oldu. Yüksek lisans derecesini Dokuz Eylül Üniversitesi Sosyal Bilimler Enstitüsü Turizm İșletmeciliği Anabilim dalından 2015 yılında aldı. Halen 2015 yılında kabul edildiği Dokuz Eylül Üniversitesi Sosyal Bilimler Enstitüsü Turizm İșletmeciliği Doktora Programı'nda eğitimine devam etmektedir. Temel çalışma alanları; Destinasyon Pazarlaması ve Tüketici Davranışları'dır.

\section{Volkan BAHÇECI}

Dokuz Eylül Üniversitesi İşletme Fakültesi Turizm İşletmeciliği bölümünden mezun oldu (2005). Yüksek lisans derecesini Dokuz Eylül Üniversitesi'nden Turizm İşletmeciliği dalından (2015) aldı. Doktora eğitimine Dokuz Eylül Üniversitesi'nde devam etmektedir. Askerlik hizmetini tamamladıktan sonra (2006) özel sektörde dış ticaret, satış ve pazarlama alanlarında çalıştı (20072012). Dokuz Eylül Üniversitesi'nde çalışmaya başladı (2012). Hâlen Dokuz Eylül Üniversitesi İşletme Fakültesinde görev yapmaktadır. Temel çalışma alanları yiyecek-içecek işletmeciliği ile turizm muhasebesi ve finansmanıdır.

\section{Hümeyra DOĞRU}

Boğaziçi Üniversitesi Uygulamalı Bilimler Yüksekokulu Turizm İşletmeciliği bölümünden 2009 yılında mezun oldu. Yüksek lisans derecesini 2015 yılında Dokuz Eylül Üniversitesi, Sosyal Bilimler Enstitüsü, Turizm İşletmeciliği daIından aldı ve doktora eğitimine Dokuz Eylül Üniversitesi Turizm İşletmeciliği bölümünde devam etmektedir. 2009-2011 yılları arasında turizm sektöründe Metglobal firmasında çevrimiçi pazarlama uzmanı olarak ve 2011-2013 yılları arasında Booking.com firmasında Türkiye Otelleri Koordinatörü olarak çalıștı. 2013 yılından itibaren Dokuz Eylül Üniversitesi İşletme Fakültesi Turizm İşletmeciliği bölümünde araştırma görevlisi olarak görev yapmaktadır. Temel çalışma alanları; turizm pazarlaması, tüketici davranışları ve elektronik turizmdir.

\section{Zehra Gökçe SEL}

Dokuz Eylül Üniversitesi İşletme Fakültesi Turizm Iş̧letmeciliği Bölümü'nden 2013 yılında fakülte ikincilik derecesiyle mezun oldu. Aynı zamanda Dokuz Eylül Üniversitesi İşletme Fakültesi'nde pazarlama yan dalı yaptı. Dokuz Eylül Üniversitesi, Sosyal Bilimler Enstitüsü Turizm İşletmeciliği Anabilim dalında yapmış olduğu yüksek lisans programından 2015 yılında mezun oldu. Hali hazırda 2015 yılında Sosyal Bilimler Enstitüsü Turizm İşletmeciliği Anabilim dalında başlamış olduğu doktora programına devam etmektedir. 2008-2013 yılları arasında yaz aylarında çeşitli turizm işletmelerinde (otel ve havalimanı işletmesi) görev aldı. 2013 yılında yüksek lisans yaparken "Öğretim Üyesi Yetiştirme Programı” ile Celal Bayar Üniversitesi Turizm İşletmeciliği Bölümü'ne araștırma görevlisi olarak atandı. Yine aynı yıl içerisinde geçici görevlendirme yapılması kaydıyla, Dokuz Eylül Üniversitesi'nde çalışmaya başladı. Halen Dokuz Eylül Üniversitesi, İșletme Fakültesi Turizm İșletmeciliği Bölümü'nde görev yapmaktadır. Temel çalışma alanları; pazarlama ve etkinlik yönetimidir.

\section{Mehmet ERTAŞ}

Çukurova Üniversitesi Turizm İşletmeciliği ve Otelcilik Yüksekokulu Konaklama İșletmeciliği Bölümünden 2011 yılında mezun oldu. Yüksek lisans derecesini Dokuz Eylül Üniversitesi Turizm İşletmeciliği dalından 2014 yılında aldı. Doktoraya 2015 yılında Dokuz Eylül Üniversitesi Turizm İşletmeciliği Bölümünde başladı ve halen devam etmektedir. 2012 yılında Pamukkale Üniversitesi'nde çalışmaya başladı. 2013 yılında 35. Madde ile Dokuz Eylül Üniversitesi İşletme Fakültesi Turizm İşletmeciliği Bölümünde çalışmaya başladı ve halen Dokuz Eylül Üniversitesi İşletme Fakültesi Turizm İşletmeciliği Bölümünde görev yapmaktadır. Temel çalışma alanları; Turizm Pazarlaması, Destinasyon Pazarlaması ve Tüketici Davranışları'dır. 


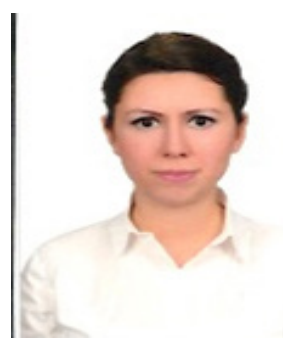

\section{Seren SONGÜR}

Dokuz Eylül Üniversitesi, ỉktisadi İdari Bilimler Fakültesi İşletme Bölümü'nden 2009 yılında mezun oldu. Yüksek lisansını, İzmir Ekonomi Üniversitesi Sosyal Bilimler Enstitüsü Lojistik Yönetimi Bölümü'nde 2012-2014 yılları arasında tamamladı. 2011-2015 yılları arasında özel sektörde çeşitli görevlerde çalıştıktan sonra 2015 yılında Dokuz Eylül Üniversitesi, Sosyal Bilimler Enstitüsü, Turizm İşletmeciliği dalında doktora eğitimine başlamıştır. Doktora öğrenimini sürdürmektedir. Temel çalışma alanları; Sürdürülebilirlik ve Yiyecek-içecek İşletmeciliği'dir.

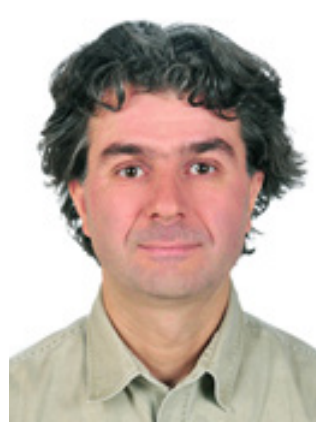

\section{Özkan TÜTÜNCÜ}

Çukurova Üniversitesi, Mersin Turizm İşletmeciliği ve Otelcilik Yüksekokulu'ndan 1988 yilında mezun oldu. Yüksek lisans ve doktora derecesini Dokuz Eylül Üniversitesi, Sosyal Bilimler Enstitüsü Turizm İşletmeciliği Anabilim dalından 1998 yılında aldı. Özel sektörde 1988-1989 tarihlerinde, dağcılık ve rafting rehberliği yaptı. 1990-1991 yıllarında TURBAN Gümüldür tesislerinde önbüroda çalıştı. Vatani görevini tamamladıktan sonra 1993 yılında Dokuz Eylül Üniversitesi'nde çalışmaya başladı. Doçentlik unvanını 2003 yılında Yönetim ve Organizasyon alanında aldı. Dokuz Eylül Üniversitesi'nde 2010 yılında profesörlüğe yükseltildi. Halen Dokuz Eylül Üniversitesi, Spor Bilimleri ve Teknolojisi Yüksekokulu, Rekreasyon Bölümü'nde görev yapmaktadır. Temel çalışma alanları; iş ve yaşam kalitesidir. 